Prepared in cooperation with the U.S. Department of Energy Office of Environmental Management, National Nuclear Security Administration, Nevada Site Office, under Interagency Agreement DE-EM0004969

\title{
Estimation of Groundwater Flow Through Yucca Flat Based on a Multiple-Well Aquifer Test at Well ER-6-1-2 Main, Nevada National Security Site, Southern Nevada
}

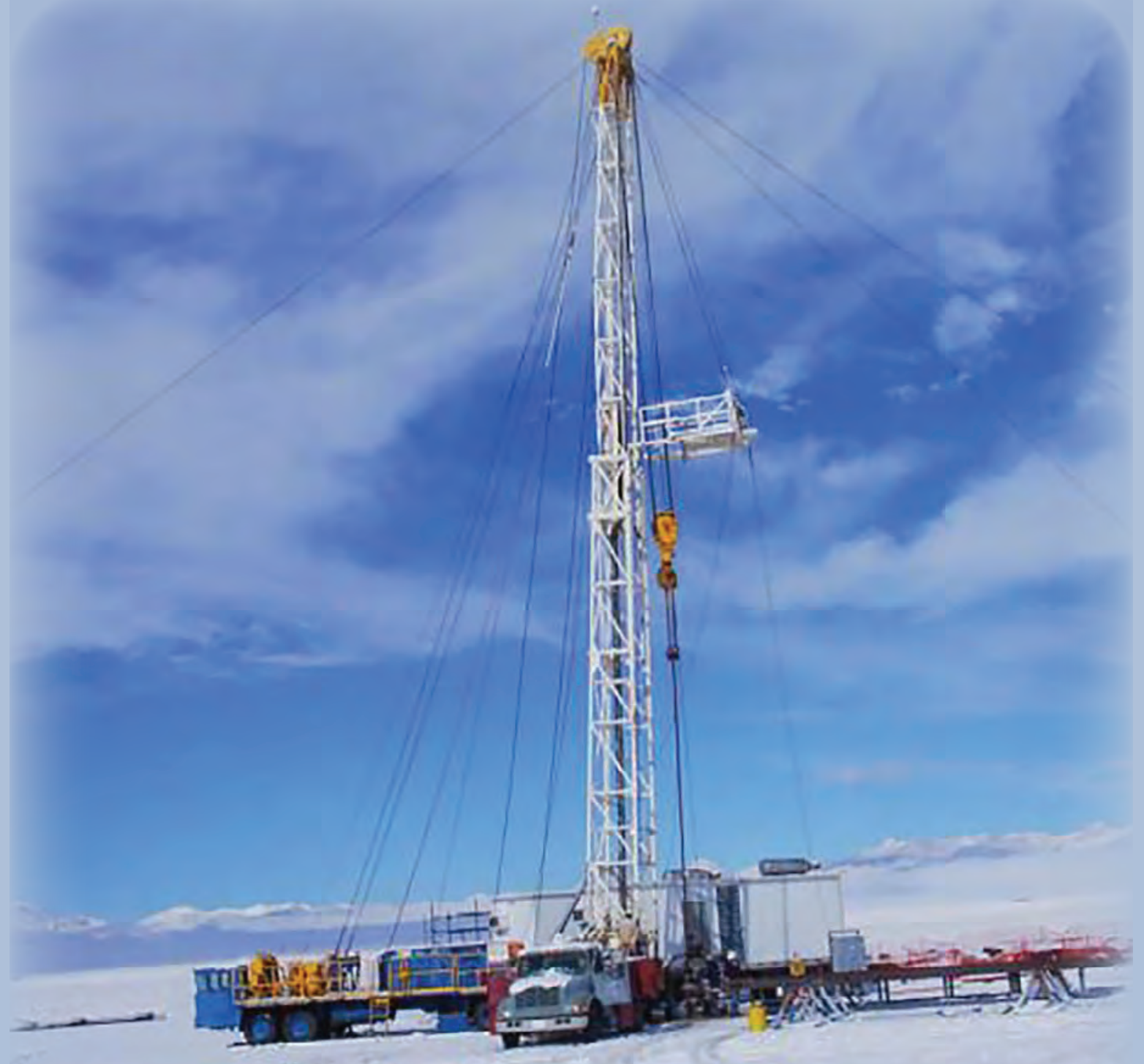

Scientific Investigations Report 2019-5038 
Cover photograph: Franks 300 mobile drill rig in about 4 inches of snow at borehole ER-6-1 in Yucca Flat, Nevada National Security Site, Nye County, southern Nevada. Borehole ER-6-1 was drilled in the early 1990s and two bridge plugs were installed to prevent natural vertical circulation of groundwater within the open borehole. In preparation for the multiple-well aquifer test in 2004 at ER-6-1-2 main, bridge plugs were removed from borehole ER-6-1, and a well packer was used to divide the main completion of borehole ER-6-1 into a lower and upper zone. Borehole ER-6-1 was developed during January 22-29, 2004, with about 1.1 million gallons pumped. Photograph by Stoller-Navarro Joint Venture staff, February 3, 2004, used with permission. 


\section{Estimation of Groundwater Flow Through Yucca Flat Based on a Multiple-Well Aquifer Test at Well ER-6-1-2 Main, Nevada National Security Site, Southern Nevada}

By Tracie R. Jackson and Keith J. Halford

Prepared in cooperation with the U.S. Department of Energy Office of

Environmental Management, National Nuclear Security Administration, Nevada

Site Office, under Interagency Agreement DE-EM0004969

Scientific Investigations Report 2019-5038 


\title{
U.S. Department of the Interior \\ DAVID BERNHARDT, Secretary
}

\author{
U.S. Geological Survey \\ James F. Reilly, Director
}

U.S. Geological Survey, Reston, Virginia: 2019

For more information on the USGS - the Federal source for science about the Earth, its natural and living resources, natural hazards, and the environment—visit https://www.usgs.gov or call 1-888-ASK-USGS.

For an overview of USGS information products, including maps, imagery, and publications, visit https://store.usgs.gov/.

Any use of trade, firm, or product names is for descriptive purposes only and does not imply endorsement by the U.S. Government.

Although this information product, for the most part, is in the public domain, it also may contain copyrighted materials as noted in the text. Permission to reproduce copyrighted items must be secured from the copyright owner.

Suggested citation:

Jackson, T.R., and Halford, K.J., 2019, Estimation of groundwater flow through Yucca Flat based on a multiple-well aquifer test at well ER-6-1-2 main, Nevada National Security Site, southern Nevada: U.S. Geological Survey Scientific Investigations Report 2019-5038, 27 p., https://doi.org/10.3133/sir20195038.

Associated data for this publication:

Jackson, T.R., Halford, K.J., and Fenelon, J.M., 2019, Supplemental data for estimation of groundwater flow through Yucca Flat based on a multiple-well aquifer test at well ER-6-1-2 main, Nevada National Security Site, southern Nevada: U.S. Geological Survey data release, https:/doi.org/10.5066/PgU2WG04.

ISSN 2328-0328 (online) 


\section{Contents}

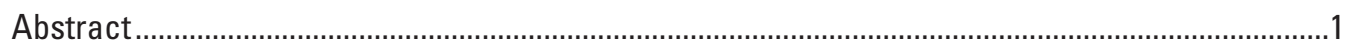

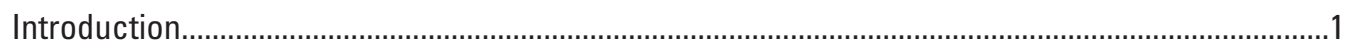

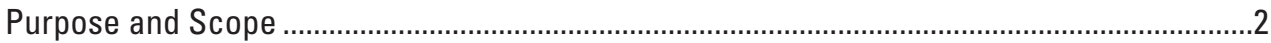

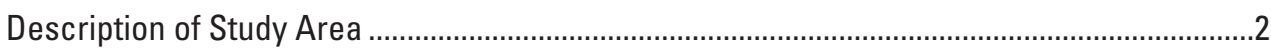

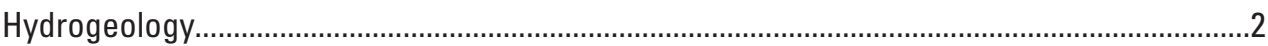

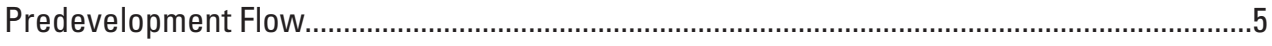

ER-6-1-2 Main Multiple-Well Aquifer Test..........................................................................

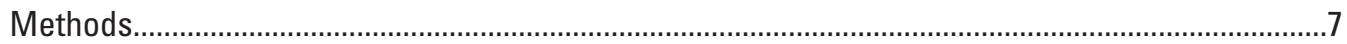

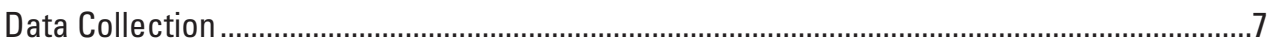

Drawdown Estimation ...................................................................................................

Continuous Data and Water-Level Models.....................................................................

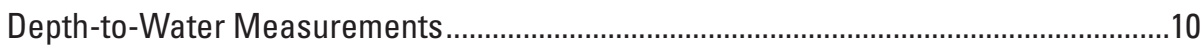

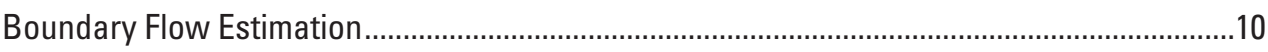

Estimation of Hydraulic Properties and Numerical Model Description .........................10

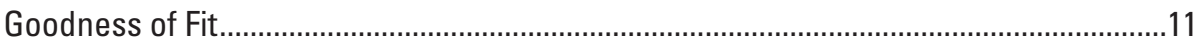

Flow Computation Approaches ..................................................................................12

Hydraulic Responses from ER-6-1-2 Main Multiple-Well Aquifer Test..........................................16

Observation Wells with Continuous Water-Level Data .........................................................16

Observation Wells with Manual Measurements.................................................................16

Hydraulic Connections in Lower Carbonate Aquifer ..........................................................16

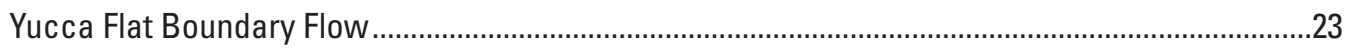

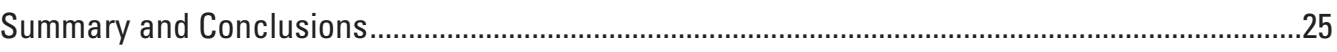

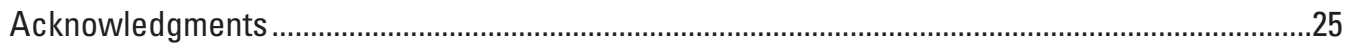

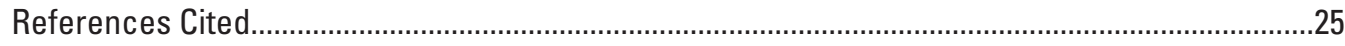

\section{Figures}

1. Map showing location of pumping and observation wells, groundwater discharge area, physiographic features, and groundwater basins surrounding the Ash Meadows groundwater basin, Nevada and California.

2. Map showing hydrogeologic units at the water table, directions of groundwater flow, and location of pumping and observation wells, Yucca Flat sub-basin and vicinity, southern Nevada.

3. Graphs showing water levels in and groundwater-withdrawal rates and cumulative withdrawals from well ER-6-1-2 main during well development, step-drawdown testing, and two constant-rate tests, Yucca Flat sub-basin, southern Nevada, February 5-July 23, 2004.

4. Graphs showing comparison of measured and simulated altitudes of all observations used in the Death Valley (version 3) steady-state model (DV3-SS) and observations in Yucca Flat sub-basin, southern Nevada...

5. Graphs showing comparison of measured and simulated water-level altitudes of wells extending north-south and west-east across Yucca Flat sub-basin, and map showing spatial locations of these wells in Yucca Flat sub-basin, southern Nevada 


\section{Figures-Continued}

6. Map showing pumping and observation wells, simulated water-level contours and transmissivity, and physiographic features, Yucca Flat sub-basin and vicinity, southern Nevada...

7. Graphs showing estimated drawdown analysis results for wells $E R-6-1-1$, ER-6-1 main (lower zone), ER-6-1 main (upper zone), ER-7-1, ER-3-1-2 (shallow), ER-6-1-2 piezometer, and UE-1h, Yucca Flat sub-basin, southern Nevada

8. Graphs showing estimated drawdown analysis results for Tracer Well 3, Ash Meadows groundwater basin, southern Nevada, 2003-05.

9. Graphs showing depth-to-water measurements and water-level change (estimated drawdowns) in wells Army 1 WW, U-3cn 5, UE-7nS, UE-10j $(2232-2297 \mathrm{ft})$, and $W W-2(3422 \mathrm{ft})$, and groundwater withdrawals in wells ER-6-1-2 main and Army 1 WW, Yucca Flat sub-basin and vicinity, southern Nevada, 2000-08 (for depth-to-water-measurements) and 2003-04 (for drawdowns)

10. Graphs showing estimated and simulated drawdowns in observation wells continuously monitored for the ER-6-1-2 main multiple-well aquifer test, Yucca Flat sub-basin and vicinity, southern Nevada.

11. Graphs showing estimated and simulated drawdowns in observation wells measured periodically during the ER-6-1-2 main multiple-well aquifer test, Yucca Flat sub-basin and vicinity, southern Nevada.

12. Graph showing estimated and simulated drawdowns in Tracer Well 3 continuously monitored for the ER-6-1-2 main multiple-well aquifer test, Yucca Flat sub-basin and vicinity, southern Nevada

13. Map showing physiographic features, pumping and observation wells, and simulated transmissivity and groundwater flow, Yucca Flat sub-basin and vicinity, southern Nevada

\section{Tables}

1. Well location and construction information for pumping and observation wells monitored during ER-6-1-2 main development and aquifer testing, Ash Meadows groundwater basin, southern Nevada

2. Estimated drawdowns in observation wells from ER-6-1-2 main development and testing, Ash Meadows groundwater basin, southern Nevada 


\section{Conversion Factors}

U.S. customary units to International System of Units

\begin{tabular}{|c|c|c|}
\hline Multiply & By & To obtain \\
\hline \multicolumn{3}{|c|}{ Length } \\
\hline inch (in.) & 25.4 & millimeter $(\mathrm{mm})$ \\
\hline foot $(\mathrm{ft})$ & 0.3048 & meter (m) \\
\hline mile (mi) & 1.609 & kilometer (km) \\
\hline \multicolumn{3}{|c|}{ Area } \\
\hline square mile $\left(\mathrm{mi}^{2}\right)$ & 2.590 & square kilometer $\left(\mathrm{km}^{2}\right)$ \\
\hline \multicolumn{3}{|c|}{ Volume } \\
\hline acre-foot (acre-ft) & 1,233 & cubic meter $\left(\mathrm{m}^{3}\right)$ \\
\hline million gallons (Mgal) & 3,785 & cubic meter $\left(\mathrm{m}^{3}\right)$ \\
\hline \multicolumn{3}{|c|}{ Flow rate } \\
\hline acre-foot per year (acre-ft/yr) & 1,233 & cubic meter per year $\left(\mathrm{m}^{3} / \mathrm{yr}\right)$ \\
\hline cubic foot per second $\left(\mathrm{ft}^{3} / \mathrm{s}\right)$ & 0.02832 & cubic meter per second $\left(\mathrm{m}^{3} / \mathrm{s}\right)$ \\
\hline gallon per minute (gal/min) & 0.06309 & liter per second $(\mathrm{L} / \mathrm{s})$ \\
\hline \multicolumn{3}{|c|}{ Hydraulic conductivity } \\
\hline foot per day (ft/d) & 0.3048 & meter per day $(\mathrm{m} / \mathrm{d})$ \\
\hline \multicolumn{3}{|c|}{ Hydraulic gradient } \\
\hline foot per foot $(\mathrm{ft} / \mathrm{ft})$ & 1 & meter per meter $(\mathrm{m} / \mathrm{m})$ \\
\hline foot per mile (ft/mi) & 0.000189 & meter per meter $(\mathrm{m} / \mathrm{m})$ \\
\hline \multicolumn{3}{|c|}{ Transmissivity } \\
\hline foot squared per day $\left(\mathrm{ft}^{2} / \mathrm{d}\right)$ & 0.09290 & meter squared per day $\left(\mathrm{m}^{2} / \mathrm{d}\right)$ \\
\hline \multicolumn{3}{|c|}{ Pressure } \\
\hline pounds per square inch $\left(\mathrm{lb} / \mathrm{in}^{2}\right)$ & $6,894.75$ & Pascal (Pa) \\
\hline
\end{tabular}

International System of Units to U.S. customary units

\begin{tabular}{llll}
\hline & Multiply & By & To obtain \\
\hline meter $(\mathrm{m})$ & Length & & \\
\hline
\end{tabular}

Temperature in degrees Celsius $\left({ }^{\circ} \mathrm{C}\right)$ may be converted to degrees Fahrenheit $\left({ }^{\circ} \mathrm{F}\right)$ as:

$$
{ }^{\circ} \mathrm{F}=\left(1.8 \times{ }^{\circ} \mathrm{C}\right)+32 \text {. }
$$

Temperature in degrees Fahrenheit $\left({ }^{\circ} \mathrm{F}\right)$ may be converted to degrees Celsius $\left({ }^{\circ} \mathrm{C}\right)$ as:

$$
{ }^{\circ} \mathrm{C}=\left({ }^{\circ} \mathrm{F}-32\right) / 1.8 \text {. }
$$




\section{Datums}

Vertical coordinate information is referenced to the National Geodetic Vertical Datum of 1929 (NGVD 29).

Horizontal coordinate information is referenced to the North American Datum of 1983 (NAD 83).

Altitude, as used in this report, refers to distance above the vertical datum.

\section{Supplemental Information}

Transmissivity: The standard unit for transmissivity is cubic foot per day per square foot times foot of aquifer thickness ([ft $\left.\left.\mathrm{ft}^{3} \mathrm{~d}\right] / \mathrm{ft}^{2}\right) \mathrm{ft}$. In this report, the mathematically reduced form, foot squared per day $\left(\mathrm{ft}^{2} / \mathrm{d}\right)$, is used for convenience.

\section{Abbreviations}

DV3

Death Valley (version 3) regional groundwater-flow model

DV3-AM-AFFCR

Death Valley (version 3) transient model of Ash Meadows and Alkali FlatFurnace Creek Ranch basins

DV3-ER612

Death Valley (version 3) transient model of ER-6-1-2 main multiple-well aquifer test

DV3-PDVS Death Valley (version 3) transient model of Pahrump to Death Valley South groundwater basin

DV3-SS Death Valley (version 3) steady-state model

LCA lower carbonate aquifer

LCCU lower clastic confining unit

MGCU Mesozoic granite confining unit

MWAT multiple-well aquifer test

NNSS Nevada National Security Site

NWIS National Water Information System

TCU tuff confining unit

UCCU upper clastic confining unit

USGS U.S. Geological Survey

WLM water-level model 


\title{
Estimation of Groundwater Flow Through Yucca Flat Based on a Multiple-Well Aquifer Test at Well ER-6-1-2 Main, Nevada National Security Site, Southern Nevada
}

\author{
By Tracie R. Jackson and Keith J. Halford
}

\section{Abstract}

The rate of groundwater flow past underground nuclear testing areas in Yucca Flat at the Nevada National Security Site, southern Nevada, was estimated using results from the ER-6-1-2 main multiple-well aquifer test (MWAT), done during February 5-July 23, 2004. Drawdowns in 13 observation wells were evaluated from pumping in well ER-6-1-2 main and used as observations in a regional groundwater-flow model to estimate the groundwater-flow rate. Flow from southern Yucca Flat regionally was constrained by detecting drawdown in Tracer Well 3, which is 33 miles south-southwest of pumping well ER-6-1-2 main. Predevelopment flow, the ER-6-1-2 main MWAT, and regional groundwater pumping were simulated in separate models that jointly informed estimates of transmissivity and specific-yield distributions. Predevelopment flow constrained groundwater-flow estimates from southern Yucca Flat because the steady-state model correctly simulated regional groundwater discharges in the Ash Meadows groundwater basin and the surrounding basins. Less than 600 acre-feet per year of groundwater moves from underground nuclear testing areas and flows south of well ER-6-1-2 main in southern Yucca Flat.

\section{Introduction}

Yucca Flat is in the northeastern part of the Nevada National Security Site (NNSS) in Nye County, southern Nevada. From 1957 to 1992, 744 nuclear tests were detonated underground in Yucca Flat (U.S. Department of Energy, 2015). Underground nuclear testing has introduced test-generated contaminants into the groundwater system (Laczniak and others, 1996). Because of public health concerns posed by underground nuclear testing, the U.S. Department of Energy and other Federal and State agencies are interested in the rate and direction of radionuclide contaminants in groundwater potentially migrating beyond Yucca Flat and the NNSS boundary (Federal Facility Agreement and Consent Order, 1996).

Complex, three-dimensional, groundwater-flow models were developed to estimate the rate and direction of radionuclide migration in groundwater from Yucca Flat (Navarro-Intera, LLC, 2013). The primary objective of the numerical modeling effort was to forecast the extent of the 1,000-year contaminant boundary for Yucca Flat. This boundary is defined as the maximum probable extent at which the concentration of any radionuclide in groundwater exceeds the radiological standards of the Safe Drinking Water Act (U.S. Environmental Protection Agency, 2012) in a period of 1,000 years (U.S. Department of Energy, 2000). The modeling effort (Navarro-Intera, LLC, 2013) and a peer review committee (Navarro-Intera, LLC, 2015) reported a large uncertainty in the lateral extent of the contaminant boundary, where this boundary was sensitive to annual groundwater flow from southern Yucca Flat (Navarro-Intera, LLC, 2013). To reduce uncertainty in the lateral extent of the contaminant boundary, a more accurate estimate of annual groundwater flow through southern Yucca Flat is needed.

Previous estimates of groundwater-flow rates through southern Yucca Flat have ranged from less than 1,000 to greater than 33,000 acre-ft/yr. Winograd and Thordarson (1975) estimated a flow rate of less than 1,000 acre-ft/yr based on water levels, hydraulic gradients, and transmissivity estimates from aquifer tests. Groundwater-flow models of the Death Valley regional flow system estimated flow rates of 15,000 acre-ft/yr (Belcher and Sweetkind, 2010) and 2,700 acre-ft/yr (Belcher and others, 2017). A groundwater-flow and transport model of Yucca Flat estimated flow rates ranging from 5,500 to 11,000 acre-ft/yr (Navarro-Intera, LLC, 2013). The greatest estimated flow from southern Yucca Flat exceeded 33,000 acre-ft from an uncertainty analysis of flow into northern Yucca Flat (Ye and others, 2010).

Groundwater flow from Yucca Flat can be better constrained by estimating integrated hydraulic properties with a large-scale aquifer test. Well ER-6-1-2 main was pumped and water levels were observed in observation wells as part of a multiple-well aquifer test (MWAT) (Stoller-Navarro Joint Venture, 2005). About $75 \mathrm{Mgal}$ (230 acre-ft) of groundwater 
were withdrawn during ER-6-1-2 main well development and aquifer testing (Stoller-Navarro Joint Venture, 2005). Results from the ER-6-1-2 main MWAT can be used to estimate groundwater flow through southern Yucca Flat because integrated hydraulic properties of a large volume of the aquifer can be estimated where drawdowns are detected miles from the pumping well (Garcia and others, 2013; Garcia and others, 2017). Integrated hydraulic properties, such as a transmissivity-width product, constrain groundwater-flow estimates because groundwater flow is the product of transmissivity-width and horizontal hydraulic gradient. Transmissivity-width product estimates also are relatively independent of conceptual models.

\section{Purpose and Scope}

The purpose of this report is to estimate annual groundwater flow from southern Yucca Flat using results from the ER-6-1-2 main MWAT in which drawdowns were estimated in 13 observation wells. Drawdowns were differentiated from environmental fluctuations using water-level models, as described by Halford and others (2012), in eight observation wells that were monitored continuously. Drawdowns also were estimated from discrete, depth-to-water measurements in five observation wells. A regional groundwater-flow model was calibrated previously to drawdowns from the ER-6-1-2 main MWAT in addition to predevelopment water-level altitudes and discharges (Halford and Jackson, 2019). Groundwater flow from southern Yucca Flat was estimated with the regional steady-state model and transmissivity-width product analyses. Supporting data and accompanying analyses are published in an independent data release (Jackson and others, 2019).

\section{Description of Study Area}

The study area encompasses four groundwater basins: (1) Pahute Mesa-Oasis Valley; (2) Alkali Flat-Furnace Creek Ranch; (3) Pahrump to Death Valley South; and (4) Ash Meadows (fig. 1), where the focus of investigation is the Ash Meadows groundwater basin. Inclusion of the surrounding basins allows the regional groundwater-flow model to correctly simulate boundary conditions for the Ash Meadows groundwater basin and constrain groundwater flow from southern Yucca Flat.

The focused area of investigation spans from Yucca Flat sub-basin to the Ash Meadows discharge area. Yucca Flat is a $170-\mathrm{mi}^{2}$ sub-basin within the $4,200-\mathrm{mi}^{2}$ Ash Meadows groundwater basin (Fenelon and others, 2016). The Ash Meadows discharge area is the primary discharge area in the Ash Meadows groundwater basin, where groundwater discharge from springs, seeps, and phreatophytes totals 18,000 acre-ft/yr (Laczniak and others, 1999). Interbasin flow occurs north of the Ash Meadows discharge area (fig. 1), where an additional 2,500 acre-ft/yr of groundwater moves from the Ash Meadows groundwater basin to the Alkali Flat-Furnace Creek Ranch groundwater basin (Halford and Jackson, 2019).

The Ash Meadows groundwater basin is part of the Death Valley regional groundwater-flow system within the Great Basin physiographic province (Harrill and Prudic, 1998). Dominant topographic features bounding the Ash Meadows groundwater basin include (1) Belted, Groom, and Timpahute Ranges to the north; (2) Sheep and Pahranagat Ranges to the east; (3) Spring Mountains to the south; and (4) Rainier Mesa, Eleana Range, Skull Mountain, and Specter Range to the west. Yucca Flat sub-basin is bounded by (1) Quartzite Ridge to the north; (2) Halfpint Range to the east and southeast; (3) CP Hills to the south; and (3) Eleana Range, Syncline Ridge, and Mine Mountain to the west. Altitudes in the Ash Meadows groundwater basin range from about 2,200 ft in the Ash Meadows discharge area to $10,700 \mathrm{ft}$ in the Spring Mountains (fig. 1). The floor of Yucca Flat sub-basin ranges in altitude from about 3,900 to 4,500 ft from southern to northern Yucca Flat, respectively.

\section{Hydrogeology}

Previous investigators have classified geologic units into hydrogeologic units based on rock hydraulic properties (Winograd and Thordarson, 1975; Laczniak and others, 1996; Slate and others, 1999; Bechtel Nevada, 2006; Fenelon and others, 2010, 2012, 2016). Hydrogeologic units categorize geologic units as aquifers or confining units based on their ability to store and transmit groundwater.

The lower clastic confining unit (LCCU), upper clastic confining unit (UCCU), and Mesozoic granite confining unit (MGCU) are grouped in a single hydrogeologic unit because these units are hydraulically similar. LCCU, UCCU, and MGCU compose the mountain ranges bounding eastern, western, and northern Yucca Flat sub-basin, respectively (fig. 2; Sweetkind and others, 2010). LCCU consists of Neoproterozoic to Lower Cambrian quartzite, siltstone, gneiss, and schist. LCCU forms the hydrologic basement of the Ash Meadows groundwater basin and composes the eastern part of the Halfpint Range. UCCU consists of Late Devonian to Mississippian quartzites, shales, and argillites, which compose the Eleana Range, Syncline Ridge, and Mine Mountain. MGCU consists of small granitic intrusions, which occur locally near Rainier Mesa and Quartzite Ridge. LCCU, UCCU, and MGCU are characterized by negligible primary porosity and permeability but may be complexly fractured. However, discontinuous fracture networks cause these rocks to be nearly impermeable (Winograd and Thordarson, 1975).

The carbonate aquifer consists of the lower carbonate aquifer (LCA) (fig. 2). The LCA is a regional carbonate-rock aquifer that is part of the Great Basin carbonate-rock province (Prudic and others, 1995). The LCA occurs throughout the Ash Meadows groundwater basin (and much of Yucca Flat; fig. 2), consists of a thick sequence of Paleozoic limestones and 


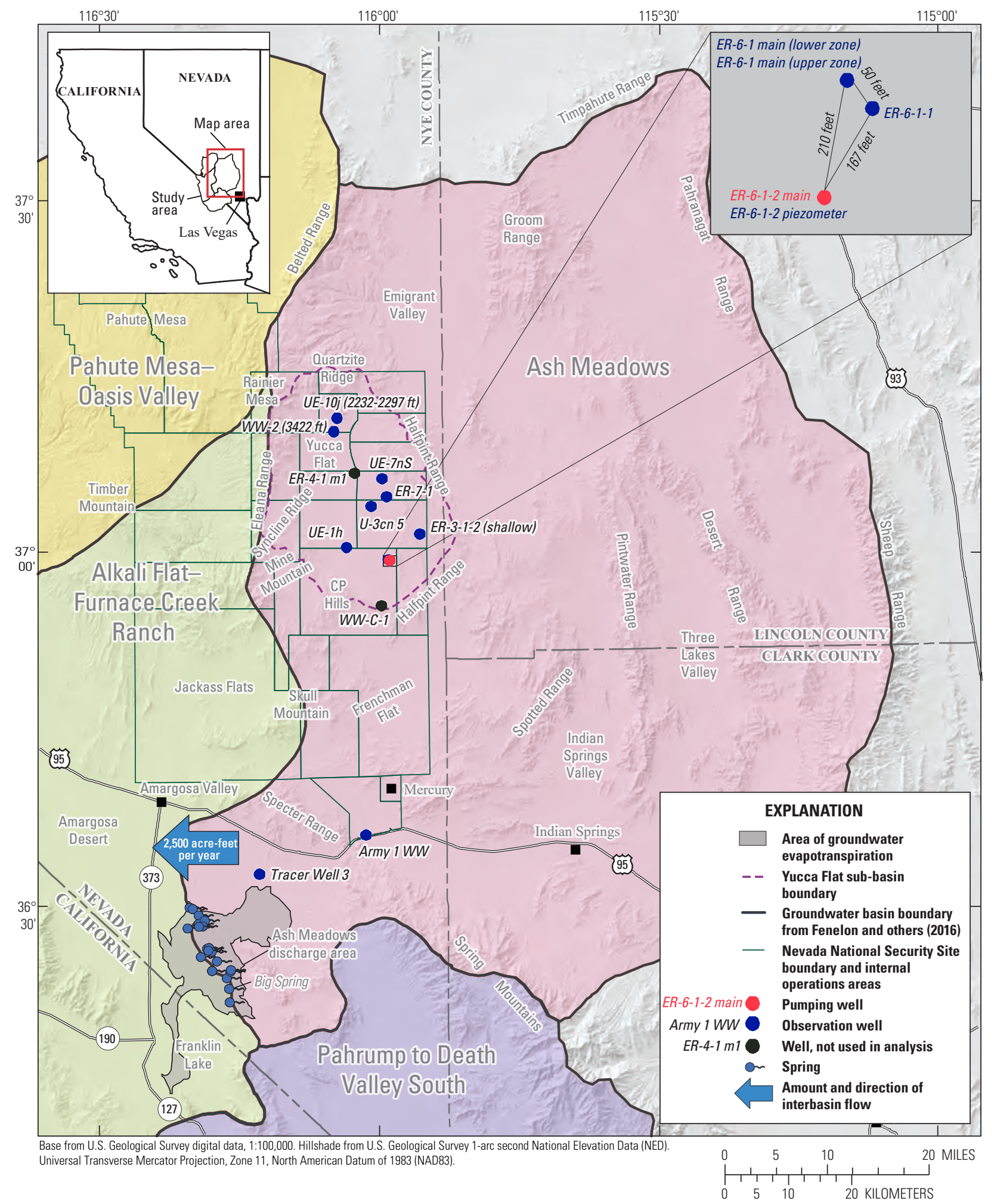

Figure 1. Location of pumping and observation wells, groundwater discharge area, physiographic features, and groundwater basins surrounding the Ash Meadows groundwater basin, Nevada and California. 


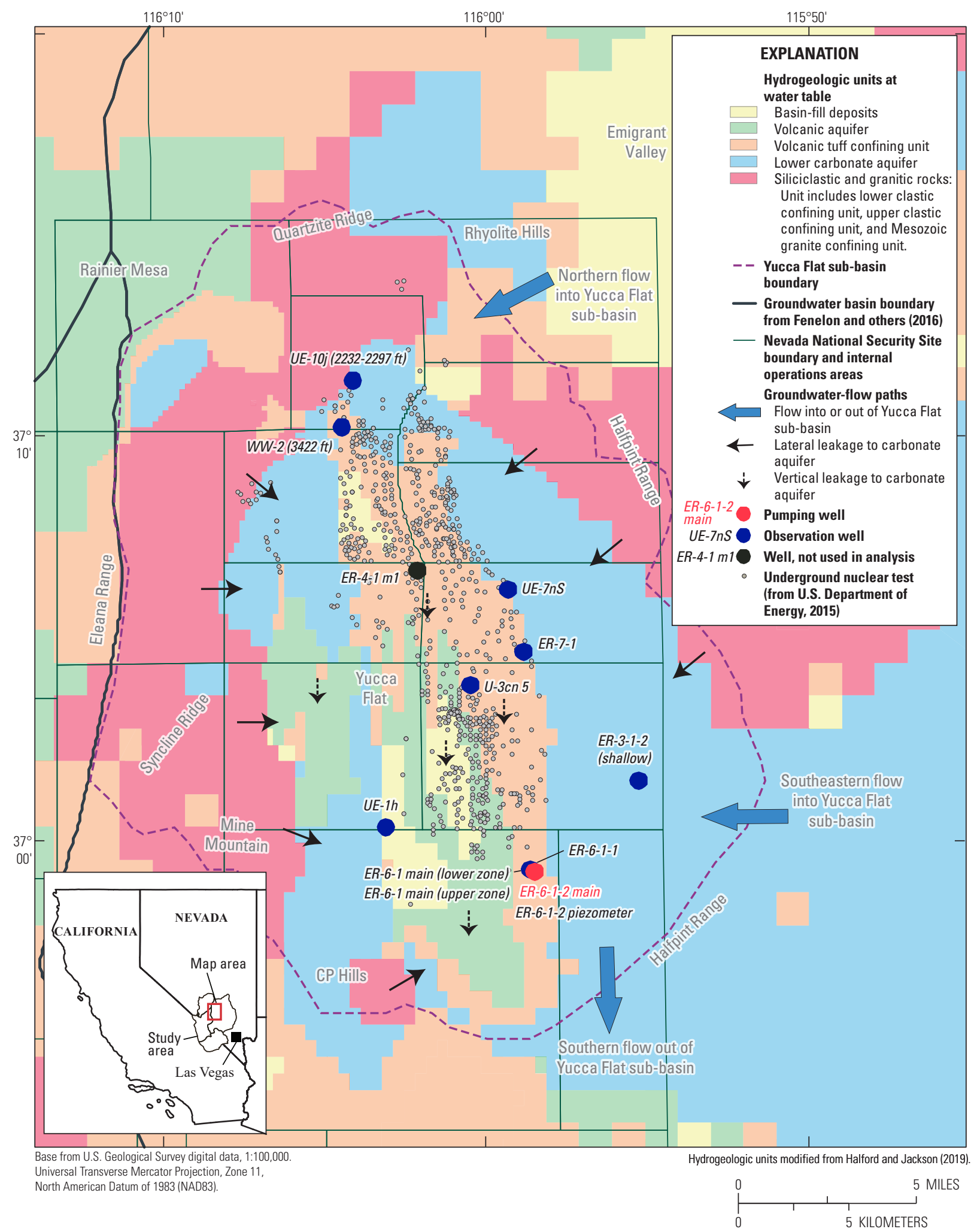

Figure 2. Hydrogeologic units at the water table, directions of groundwater flow, and location of pumping and observation wells, Yucca Flat sub-basin and vicinity, southern Nevada. 
dolostones, and has saturated thicknesses of more than 15,000 $\mathrm{ft}$ in some areas (Laczniak and others, 1996). However, only the upper few thousand feet of saturated LCA are considered hydraulically active, with little flow occurring in the deeper parts (Fenelon and others, 2012). These rocks have negligible matrix porosity and permeability. Aquifer-test results indicate that the LCA has a wide range in transmissivity (from less than $100 \mathrm{ft}^{2} / \mathrm{d}$ to more than $1,000,000 \mathrm{ft}^{2} / \mathrm{d}$ ) because of variable faulting and fracturing (Winograd and Thordarson, 1975).

Thin, localized volcanic aquifers occur in Yucca Flat (fig. 2). Volcanic aquifers consist of moderately to densely welded ash-flow tuffs, where fracturing causes a laterally extensive and hydraulically connected fracture network (Winograd and Thordarson, 1975; Laczniak and others, 1996). Volcanic aquifers have saturated thicknesses of less than 2,000 $\mathrm{ft}$ in Yucca Flat sub-basin (Fenelon and others, 2012).

Basin-fill deposits form thin, localized aquifers and confining units in the intermontane basins within the Ash Meadows groundwater basin (Sweetkind and others, 2010). Coarse-grained basin fill typically consists of alluvial and colluvial deposits with minor fluvial, debris-flow, and eolian deposits (Slate and others, 1999). Coarse-grained deposits are characterized by high matrix porosity and permeability, and typically form aquifers. Fine-grained basin fill forms confining units, which consist of playa and lacustrine sediments. Basin-fill deposits increase in thickness from the margins to the center of intermontane basins (Bechtel Nevada, 2006), and are unsaturated throughout most of Yucca Flat (fig. 2). However, basin-fill aquifers have saturated thicknesses of less than 1,500 $\mathrm{ft}$ in localized areas along the central corridor of Yucca Flat (Fenelon and others, 2012).

A thick volcanic tuff confining unit (TCU) forms a hydraulic barrier between overlying basin-fill and volcanic aquifers and the underlying LCA throughout most of Yucca Flat sub-basin (fig. 2; Fenelon and others, 2012). Rocks composing the TCU are commonly zeolitized and consist of nonwelded or partially welded ash-flow tuffs, bedded tuffs, and reworked tuffaceous sediments (Winograd and Thordarson, 1975; Sawyer and others, 1994; Laczniak and others, 1996). These rocks typically form confining units because mineral alteration to zeolites reduces matrix permeability and the low susceptibility of these rocks to strain fracture reduces fracture permeability (Fenelon and others, 2012). The saturated thickness of the TCU typically ranges from 500 to 2,000 ft and is more than 2,500 ft in central Yucca Flat (Fenelon and others, 2012).

\section{Predevelopment Flow}

Groundwater recharge occurs where precipitation infiltrates permeable rocks and percolates below the root zone to the water table, either through an interconnected network of fractures or the rock matrix. Greater amounts of precipitation occur at higher altitudes; consequently, greater amounts of recharge typically occur in highland areas. An exception to this conceptualization occurs where low-permeability rocks underlie highland areas. In these areas, precipitation from snowmelt (or high-intensity rainfall) flows downgradient and infiltrates adjacent alluvial-fan deposits. Some surface runoff, and subsequent recharge, occurs in ephemeral channels draining highland areas.

More groundwater recharge is derived from mountain ranges bounding the Ash Meadows groundwater basin than from ranges bounding Yucca Flat sub-basin. Potential groundwater recharge for most of the Ash Meadows groundwater basin occurs in highland areas such as the Spring Mountains, and the Belted, Groom, Timpahute, Pahranagat, Sheep, Desert, Pintwater, and Spotted Ranges (fig. 1; Fenelon and others, 2016). Potential groundwater recharge to Yucca Flat sub-basin occurs locally from precipitation infiltrating bounding ranges, including the Eleana, Belted, and Halfpint Ranges; CP Hills; Mine Mountain; and Syncline Ridge (Fenelon and others, 2012). Substantially less precipitation and recharge occur in Yucca Flat sub-basin than in the Ash Meadows groundwater basin because highland areas bounding the sub-basin have altitudes of 4,000-7,000 ft, whereas highland areas bounding the Ash Meadows groundwater basin have altitudes of $6,000-10,700 \mathrm{ft}$.

Groundwater generally moves in a south-southwest direction in the Ash Meadows groundwater basin (Fenelon and others, 2016). Groundwater moves from highland recharge areas to areas where groundwater discharges predominantly at springs and seeps. The two areas of groundwater discharge in the Ash Meadows groundwater basin are at Indian Springs and Ash Meadows discharge area. An additional amount of groundwater moves as interbasin flow from the Ash Meadows groundwater basin to the Alkali Flat-Furnace Creek Ranch groundwater basin (fig. 1).

Water levels, hydraulic gradients, and geologic evidence indicate that all groundwater leaves Yucca Flat through the LCA (Winograd and Thordarson, 1975; Fenelon and others, 2012). Thin, localized basin-fill and volcanic rocks form a laterally continuous aquifer in the central part of Yucca Flat (fig. 2). Lateral movement of groundwater from basin-fill and volcanic aquifers to areas downgradient of Yucca Flat is prohibited by the TCU, which acts as a flow barrier (Winograd and Thordarson, 1975). Instead, hydraulic gradients indicate lateral groundwater flow toward a hydraulic sink in central Yucca Flat. Water levels in these aquifers are elevated 20-100 $\mathrm{ft}$ above water levels in the LCA (Fenelon and others, 2012). The presence of a hydraulic sink and elevated water levels indicates that groundwater moves downward as vertical leakage across the TCU into the underlying LCA (Winograd and Thordarson, 1975). Potentiometric contours show that, once groundwater moves into the LCA, groundwater moves southward out of Yucca Flat sub-basin to downgradient discharge areas (Fenelon and others, 2012).

Predevelopment groundwater-flow rates in the LCA through Yucca Flat sub-basin range from 350 to 1,000 acre-ft/ yr (Winograd and Thordarson, 1975; Harrill and others, 1988; Fenelon and others, 2016). These groundwater-flow rates were 
estimated using Darcy's law or basin flow balance approaches. Estimated groundwater-flow rates account for locally derived recharge into highland areas bounding the sub-basin, and groundwater flow that enters the sub-basin from the north and southeast (fig. 2).

Locally derived recharge in Yucca Flat sub-basin moves vertically and laterally from the surrounding rocks into the LCA. Winograd and Thordarson (1975) estimated vertical leakage rates through the TCU ranging from 25 to 65 acre-ft/ yr. These estimates were computed with Darcy's law using a vertical hydraulic gradient of $0.2 \mathrm{ft} / \mathrm{ft}$; vertical hydraulic conductivities of $8 \times 10^{-6}$ and $2 \times 10^{-5} \mathrm{ft} / \mathrm{d}$, based on 38 core samples of the TCU; and a surficial area of the TCU in contact with LCA of $66 \mathrm{mi}^{2}$. Most lateral leakage into the LCA likely occurs from precipitation-derived recharge from highlands in the west and northeast (Fenelon and others, 2012), where Winograd and Thordarson (1975) estimated a lateral leakage rate of 250 acre-ft/yr. Harrill and others (1988) estimated a total lateral and vertical leakage rate into the LCA of 700 acre-ft/yr.

Most groundwater flow enters Yucca Flat sub-basin from the Halfpint Range in the southeast (fig. 2). Winograd and Thordarson (1975) estimated a groundwater-flow rate of less than 100 acre-ft/yr into the LCA from the southeast, whereas Harrill and others (1988) estimated a groundwater-flow rate of about 300 acre-ft/yr into the LCA.

Groundwater flow may enter northern Yucca Flat sub-basin from Emigrant Valley; however, if this occurs, the flow is limited because low-permeability rocks act as a flow barrier. At the water table, Yucca Flat sub-basin is bounded by the LCCU to the northeast in the Halfpint Range, the MGCU to the north, and the UCCU to the west in the Eleana Range (fig. 2). These rocks form a hydraulic barrier, as evidenced by low transmissivities $\left(0.1 \mathrm{ft}^{2} / \mathrm{d}\right)$ and steep hydraulic gradients $(1,300 \mathrm{ft} / \mathrm{mi})$ between Emigrant Valley and Yucca Flat (Winograd and Thordarson, 1975). Using Darcy's law, Winograd and Thordarson (1975) estimated a groundwater-flow rate of less than 40 acre-ft/yr into the LCA from Emigrant Valley.

Failure to use groundwater-flow rates as constraints during calibration of numerical models has resulted in estimates that greatly exceed $40 \mathrm{acre}-\mathrm{ft} / \mathrm{yr}$ through northern Yucca Flat from Emigrant Valley. A groundwater-flow model of the Death Valley regional flow system estimated a flow rate through northern Yucca Flat of 14,000 acre-ft/ yr (Belcher and Sweetkind, 2010). This model subsequently provided boundary conditions for a Yucca Flat LCA model - a groundwater-flow and transport model of the LCA focused on Yucca Flat (Stoller-Navarro Joint Venture, 2006). Using the erroneously large flow rate from the north resulted in rapid groundwater velocities and model-estimated hydraulic properties in Yucca Flat that exceeded results from aquifer tests. An uncertainty analysis was done to bound the northern flow estimates, but that analysis also did not use a flow constraint; northern flow rates ranged from 15,000 to 33,000 acre-ft/yr (Ye and others, 2010). This range is obviously wrong because the much larger Ash Meadows groundwater basin receives about 22,000 acre-ft of annual recharge (Fenelon and others, 2016). In a revised Yucca Flat LCA model, northern flow rates ranged from 2,000 to 7,500 acre-ft/ yr (Navarro-Intera, LLC, 2013). However, these revised northern flow rates are still too high. Inflow through northern Yucca Flat is expected to be only a minor component of the total flow in the Ash Meadows groundwater basin.

Unreasonably high estimates of annual groundwater flow through northern Yucca Flat have been addressed in more recent numerical models. An updated groundwater-flow model of the Death Valley regional flow system estimated a northern flow rate of 530 acre-ft/yr (Belcher and others, 2017). The Death Valley (version 3) regional groundwater-flow model (DV3) estimated a northern flow rate of 220 acre-ft/yr (Halford and Jackson, 2019).

\section{ER-6-1-2 Main Multiple-Well Aquifer Test}

A multiple-well aquifer test (MWAT) was done in southern Yucca Flat in 2004 to investigate postulated preferential flow paths along faults in the LCA (Bechtel Nevada, 2004). The MWAT was done as part of a tracer test (Stoller-Navarro Joint Venture, 2005); however, this report focuses on analysis of the MWAT to estimate integrated hydraulic properties of and flow rates through Yucca Flat. During the MWAT, well ER-6-1-2 main was pumped, water levels were measured continuously (at 15-second or 15-minute intervals) in eight observation wells, and water levels were measured periodically (from 5 to 117 days) in five additional wells. The pumping well and eight observation wells (fig. 1; table 1) were instrumented with pressure transducers by a private contractor, Stoller-Navarro Joint Venture, and the U.S. Geological Survey (USGS). Depth-to-water in five wells was measured periodically by the USGS with calibrated electric tapes. Drawdowns from pumping well ER-6-1-2 main were estimated in the 13 monitored wells.

The horizontal distance from pumping to observation wells ranged from 0 to $33 \mathrm{mi}$. Pumping well ER-6-1-2 main and 12 observation wells are open to the LCA (table 1). Observation well ER-6-1-2 piezometer is open to the TCU. For the MWAT, a well packer divided the main completion of well ER-6-1 into a lower and upper zone, and the zones were monitored separately.

Well ER-6-1-2 main was pumped during February 5July 23, 2004 (Stoller-Navarro Joint Venture, 2005). Pumping included well development and step-drawdown testing, a 9-day constant-rate test, and a 90-day constant-rate test (fig. 3). Well development and step-drawdown testing occurred from February 5 to 11, 2004. The 9-day constant-rate test was done during February 12-21, 2004, where well ER-6-1-2 main was pumped at a constant rate of about $522 \mathrm{gal} / \mathrm{min}$. About 11 Mgal of groundwater were withdrawn from February 5 to 21, 2004, during well development, step-drawdown testing, and the 9-day constant-rate test. The 90-day constant-rate test 
Table 1. Well location and construction information for pumping and observation wells monitored during ER-6-1-2 main development and aquifer testing, Ash Meadows groundwater basin, southern Nevada.

[USGS site identification number: Unique 15-digit, U.S. Geological Survey site identification number. USGS well name: U.S. Geological Survey well name. Latitude: Latitude, in decimal degrees; referenced to the North American Datum of 1983 (NAD 83). Longitude: Longitude, in decimal degrees; referenced to NAD 83. Land-surface altitude: Altitude of land surface at well site, referenced to feet above National Geodetic Vertical Datum of 1929 (NGVD 29). Depth of borehole: Total depth of borehole, in feet below land surface. Open interval: Area of well that is open to aquifer and where, if saturated, groundwater may enter the well. Open interval typically consists of open borehole and (or) well screen, including gravel pack. Where multiple open intervals occur in a well, depths are to top of the uppermost interval and bottom of the lowermost interval. Primary hydrogeologic unit: Primary water-bearing hydrogeologic unit within the open interval that is contributing water to the well: LCA, lower carbonate aquifer; and TCU, tuff confining unit]

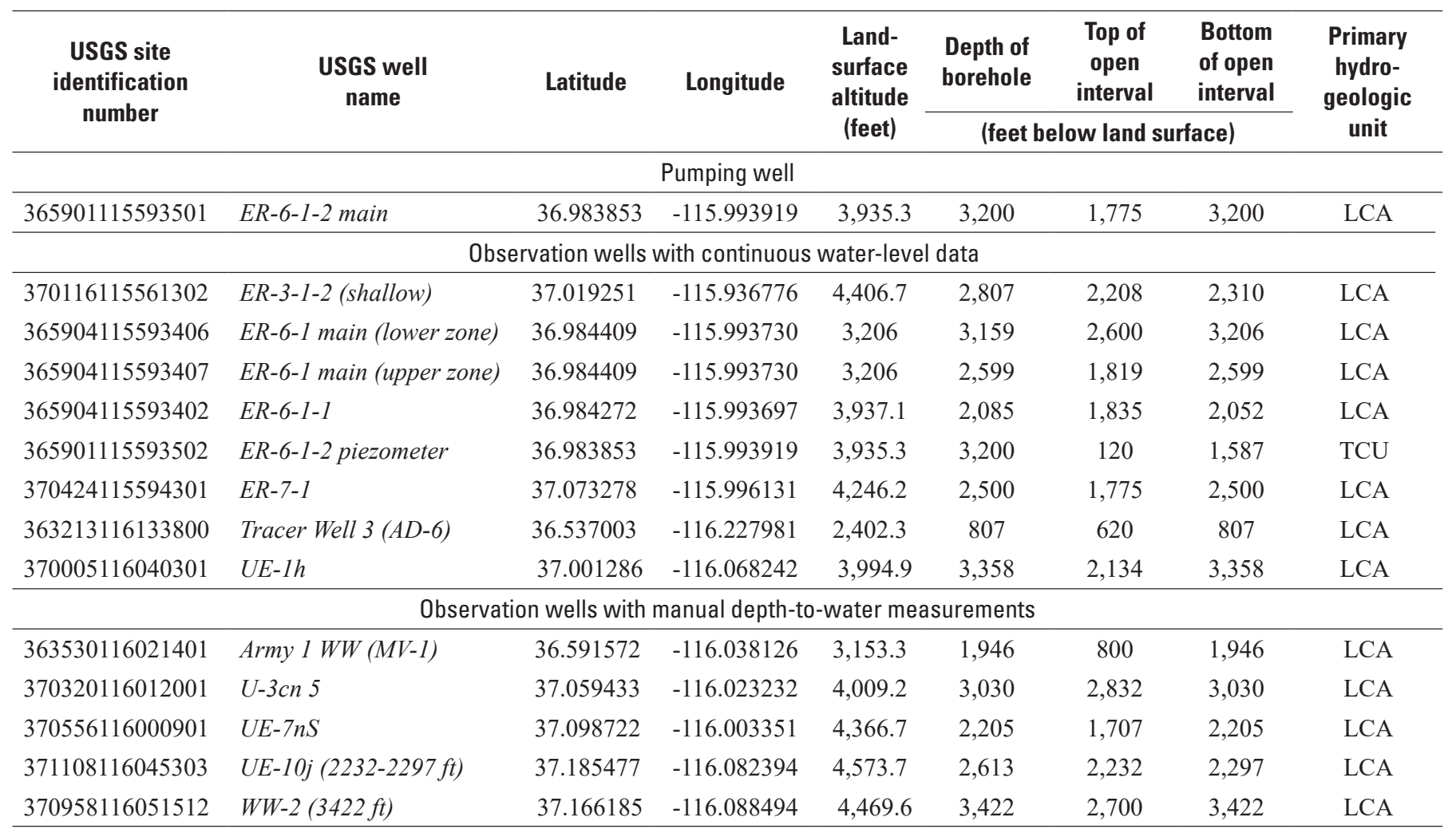

was done during April 24-July 23, 2004, where well ER-6-1-2 main was pumped at a constant rate of about $524 \mathrm{gal} / \mathrm{min}$, and about $64 \mathrm{Mgal}$ of groundwater were withdrawn. The 90-day constant-rate test had a scheduled pumping interruption from July 8, 2004 at 1655 hours to July 12, 2004 at 0735 hours to create a calibration point for tracer transport analyses (Stoller-Navarro Joint Venture, 2005). Well development, step-drawdown testing, and the constant-rate testing were considered a single MWAT because water levels likely did not recover between pumping periods, as suggested by water-level data in well ER-7-1. Withdrawals totaled about 75 Mgal.

\section{Methods}

\section{Data Collection}

Data were collected before, during, and after aquifer testing. Continuous water-level, water-temperature, and barometric-pressure data at the pumping well and at seven of eight observation wells (excluding Tracer Well 3; table 1) were obtained from Stoller-Navarro Joint Venture (2005). The pumping history for well ER-6-1-2 main during well development and aquifer testing also was obtained from Stoller-Navarro Joint Venture (2005). Continuous water-level, water-temperature, and barometric-pressure 

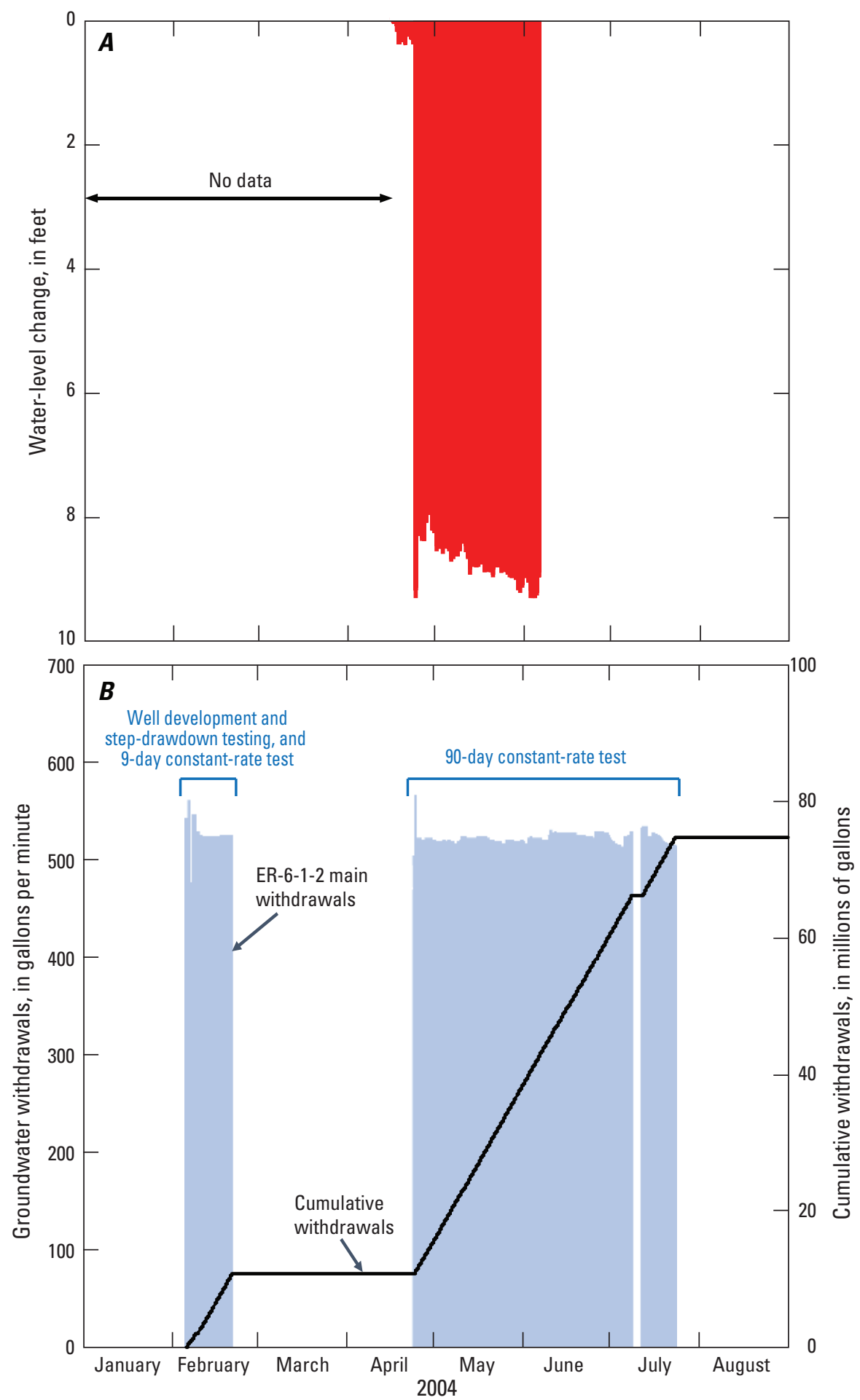

Figure 3. Water levels in $(A)$ and groundwater-withdrawal rates and cumulative withdrawals from $(B)$ well $E R-6-1-2$ main during well development, step-drawdown testing, and two constant-rate tests, Yucca Flat sub-basin, southern Nevada, February 5July 23, 2004. 
data at Tracer Well 3 and depth-to-water measurements in five observation wells (table 1) were retrieved from the USGS National Water Information System (NWIS) database (https://nwis.waterdata.usgs.gov/nwis). The pumping history for well Army $1 \mathrm{WW}$, which was used in drawdown analyses at wells Army $1 \mathrm{WW}$ and Tracer Well 3, was obtained from the USGS-U.S. Department of Energy Cooperative Studies in Nevada web (https://nevada.usgs.gov/doe_nv). Compiled continuous data, depth-to-water measurements, and groundwater-withdrawal data are provided in Jackson and others (2019).

Stoller-Navarro Joint Venture measured continuous data at the pumping well and at seven of eight observation wells (excluding Tracer Well 3), and the pumping rates for well ER-6-1-2 main. Water levels and temperature were measured using pressure transducers that either directly measure the pressure of the overlying water column (vented) or measure total pressure of the atmosphere and overlying water column (nonvented). The vented WaterLOG ${ }^{\circledR}$ Series H-310-30 pressure transducer (Design Analysis Associates, Incorporated, Logan, Utah) has a depth range of 0-69.20 $\mathrm{ft}\left[0-30 \mathrm{lb} / \mathrm{in}^{2}\right.$ gauge $]$ with an accuracy of $\pm 0.014 \mathrm{ft}$, and a temperature range of $0-40{ }^{\circ} \mathrm{C}$ with an accuracy of $\pm 1{ }^{\circ} \mathrm{C}$ (Fletcher, 2018). The nonvented Model PS9800 ${ }^{\circledR}$ pressure transducer (Seametrics, Kent, Washington) has a depth range of $0-81 \mathrm{ft}\left[0-50 \mathrm{lb} /\right.$ in $^{2}$ absolute $]$ with an accuracy of \pm 0.081 $\mathrm{ft}$, and a temperature range of $0-50{ }^{\circ} \mathrm{C}$ with an accuracy of $\pm 0.3{ }^{\circ} \mathrm{C}$ (Seametrics, 2018). Barometric pressure was measured using Model PTB-101 ${ }^{\circledR}$ barometers, which have an accuracy of $\pm 0.004 \mathrm{lb} / \mathrm{in}^{2}$ gauge at $20{ }^{\circ} \mathrm{C}\left(68^{\circ} \mathrm{F}\right)$ (Vaisala, 2005). Campbell Scientific CR10 and CR10X data loggers with integrated barometers were used to record water-level, temperature, and barometric-pressure data at the pumping and seven observation wells every 15 seconds or if a water-level change greater than $0.5 \mathrm{lb} / \mathrm{in}^{2}$ occurred. Pumping rates in well ER-6-1-2 main were measured with a 4-in. Foxboro 8004A magnetic flowmeter and integrated transmitter (series IMT 25), which transmitted production rates to a Campbell Scientific CR10X data logger. The flowmeter system measures production rates of as much as 2,000 gal/min and has a flow rate accuracy of 0.25 percent (Foxboro Company, 1997).

Manual depth-to-water measurements in five observation wells (table 1) and continuous water-level, water-temperature, and barometric-pressure data at Tracer Well 3 were measured by the USGS. Depth-to-water measurements were collected using calibrated electric tapes manufactured by Solinst Canada Limited (Georgetown, Ontario; Model 101) and RST Instruments Limited (Maple Ridge, British Columbia, Canada). The material used in Solinst electric tapes is medium-density polyethylene, whereas the material used in RST Instruments electric tapes is polyethylene-coated steel. The calibrated electric tapes are marked with $0.01-\mathrm{ft}$ graduations but have an accuracy of $+0.1 \mathrm{ft}$ (Fulford and Clayton, 2015). During the ER-6-1-2 main MWAT, water levels and temperature in Tracer Well 3 were measured continuously at 15 -minute intervals using a vented
WaterLOG ${ }^{\circledR}$ Series H-310-15 submersible pressure transducer. The pressure transducer has a depth range of $0-34.60 \mathrm{ft}(0-15$ $\mathrm{lb} / \mathrm{in}^{2}$ gauge) with an accuracy of $\pm 0.007 \mathrm{ft}$, and a temperature range of $0-40{ }^{\circ} \mathrm{C}$ with an accuracy of $\pm 1^{\circ} \mathrm{C}$ (Fletcher, 2018). Barometric pressure was measured using a Met One 090 barometer, which has a range of $8.7-14.5 \mathrm{lb} / \mathrm{in}^{2}$ gauge and an accuracy of $\pm 0.005 \mathrm{lb} / \mathrm{in}^{2}$ gauge at $20^{\circ} \mathrm{C}\left(68^{\circ} \mathrm{F}\right)$. A Sutron Model 8200 data logger with an integrated barometer was used to record water-level, temperature, and barometric-pressure data at Tracer Well 3 every 15 minutes.

\section{Drawdown Estimation}

Drawdowns at eight observation wells from pumping well ER-6-1-2 main were estimated from continuous water-level data using a water-level modeling approach (Halford and others, 2012), which uses an analytical model to fit a synthetic curve to measured water levels. The synthetic curve is the sum of one or more time-series components that explain water-level fluctuations in the measured data. Water-level models (WLMs) were used to estimate drawdowns masked by environmental noise by removing water-level fluctuations due to barometric pressure and tidal forces from the measured data. WLMs were generated using SeriesSEE, a Microsoft Excel ${ }^{\circledR}$ add-in (Halford and others, 2012). All WLM analyses discussed in this report are published in Jackson and others (2019).

Drawdowns at five observation wells from pumping well ER-6-1-2 main were estimated from manual, depth-to-water measurements. Water-level fluctuations due to barometric pressure and tidal forces were not removed from manual measurements. Visual inspection of more recent (2017) continuous water-level data in these observation wells and other wells in Yucca Flat indicate that barometric pressure and tidal forces cause water levels to fluctuate $\pm 0.2 \mathrm{ft}$. To account for water-level fluctuations due to measurement error, barometric pressure, and tidal forces, error bars of $\pm 0.2 \mathrm{ft}$ were added to provide an approximate range of uncertainty in estimated drawdowns. All drawdown analyses from depth-to-water measurements are published in Jackson and others (2019).

\section{Continuous Data and Water-Level Models}

Drawdowns were estimated with water-level modeling because environmental (non-pumping) water-level fluctuations masked drawdown from pumping in observation wells. Drawdowns in observation wells from pumping well ER-6-1-2 main were analytically modeled with a Theis transform of the pumping signal, where water-level changes from multiple pumping rates were simulated by superimposing multiple Theis (1935) solutions. Theis transforms serve as simple transform functions, where step-wise pumping records are translated into approximate water-level responses. Numerical experiments have confirmed that superimposed Theis 
transforms closely approximate water-level responses, even in hydrogeologically complex aquifer systems (Garcia and others, 2013).

Synthetic water levels in WLMs represent summed time series of water-level fluctuations resulting from earth tides, gravity tides, barometric pressure, and pumping responses. Earth and gravity tides were computed functions based on well-established theoretical equations (Harrison, 1971). Hourly-to-weekly fluctuations in barometric pressure were simulated with moving averages of barometric-pressure data measured at or near each observation well. Pumping responses (drawdowns) at an observation well were simulated with Theis transforms of the pumping schedule from well ER-6-1-2 main.

Synthetic water levels were fit to measured water levels by minimizing the root-mean-square error of differences between synthetic and measured water levels (Halford and others, 2012). Amplitude and phase were adjusted in each time series used to simulate environmental water-level fluctuations (barometric pressure and tides). Transmissivity and the storage coefficient were adjusted in the Theis transform model.

The drawdown estimate at an observation well is the summation of Theis transforms minus residual differences between synthetic and measured water levels (Halford and others, 2012). The summation of all Theis transforms is the direct estimate of the pumping signal. Residuals (measured minus synthetic water levels) represent all unexplained water-level fluctuations. These fluctuations primarily are random (noise) during non-pumping periods but can contain unexplained components of the pumping signal during pumping periods.

Drawdown detection was classified as detected or not detected based on the signal-to-noise ratio. Signal and noise are defined herein as the maximum simulated drawdown occurring in an observation well during an aquifer test and the root-mean-square error, respectively. Drawdown was classified as detected where the signal-to-noise ratio was greater than or equal to 5. Drawdown was classified as not detected where the signal-to-noise ratio was less than 5 , indicating drawdown (if any) could not be reliably differentiated from the noise.

\section{Depth-to-Water Measurements}

Drawdowns at five observation wells from pumping well ER-6-1-2 main were estimated from manual, depth-to-water measurements. Water-level declines were estimated from pumping during ER-6-1-2 main aquifer testing by subtracting depth-to-water measurements during the period of pumping from the first depth-to-water measurement prior to pumping. Error bars of $\pm 0.2 \mathrm{ft}$ were added to drawdowns to account for water-level fluctuations due to barometric pressure, tidal forces, and measurement error. Drawdowns estimated from depth-to-water measurements are less accurate than drawdowns estimated from continuous water-level data and are used to provide a qualitative comparison to numerical results.

\section{Boundary Flow Estimation}

Groundwater flow from southern Yucca Flat was estimated using a regional, three-dimensional, groundwater-flow model, referred to as Death Valley (version 3) (DV3; Halford and Jackson, 2019). The DV3 model couples steady-state (predevelopment) and transient (pumping), three-dimensional, finite-difference, numerical models (MODFLOW 2005; Harbaugh, 2005). Drawdowns estimated from continuous data and manual measurements were used as measured observations during the simulation of ER-6-1-2 main well development and aquifer testing from February 5 to July 23, 2004. The groundwater-flow rate from Yucca Flat was estimated by simultaneously calibrating to steady-state and transient conditions.

\section{Estimation of Hydraulic Properties and Numerical Model Description}

Recharge, hydraulic-conductivity, specific-yield, and specific-storage distributions were estimated by simultaneously calibrating multiple, three-dimensional, numerical groundwater models of the study area (Halford and Jackson, 2019). Multiple models were used to differentiate and better interpret effects of predevelopment flow, groundwater development, and aquifer tests on the groundwater system. Multiple models allow boundary conditions to be better constrained to known (predevelopment or pumping) conditions and to allow comparison of simulated responses to those known conditions. For example, discharge from Big Spring in the Ash Meadows discharge area (fig. 1) averaged $2.3 \mathrm{ft}^{3} / \mathrm{s}$ prior to development and the pool altitude was 2,240 $\mathrm{ft}$. Multiple models allowed simulating Big Spring as a specified discharge of $2.3 \mathrm{ft}^{3} / \mathrm{s}$ prior to development and as a capture-limited, head-dependent boundary during groundwater development. This prevented misfits between simulated and measured pool altitudes from affecting simulated capture during groundwater development.

Predevelopment conditions, the ER-6-1-2 main MWAT, groundwater development in Ash Meadows and Alkali Flat-Furnace Creek Ranch groundwater basins, and groundwater development in the Pahrump to Death Valley South groundwater basin were simulated with four separate, but coupled, groundwater-flow models. The Death Valley (version 3) steady-state model (DV3-SS) simulated predevelopment conditions and informed estimates of recharge rates and hydraulic conductivities. The Death Valley (version 3) transient model of ER-6-1-2 main multiple-well aquifer test (DV3-ER612) simulated changes from pumping during ER-6-1-2 main well development and aquifer testing from February 5 to July 23, 2004, and informed estimates of hydraulic properties between wells UE-10j (2232-2297 ft) and Tracer Well 3 (fig. 1). The Death Valley (version 3) transient model of Ash Meadows and Alkali Flat-Furnace Creek Ranch basins (DV3-AM-AFFCR) simulated changes 
from groundwater development from 1950 to 2018 in the Ash Meadows and Alkali Flat-Furnace Creek Ranch groundwater basins. The Death Valley (version 3) transient model of Pahrump to Death Valley South groundwater basin (DV3-PDVS) simulated changes from groundwater development from 1913 to 2018 in the Pahrump to Death Valley South groundwater basin. Transient DV3-ER612, DV3-AM-AFFCR, and DV3-PDVS models informed estimates of hydraulic conductivity, specific yield, and specific storage where pumping measurably changed water levels or discharges.

All groundwater-flow models shared a common domain, grid, and hydrogeologic framework. Model domains extended laterally to no-flow boundaries at the outer boundaries of the four groundwater basins (fig. 1). Each model was divided areally into 268 rows of 221 columns of variably spaced, rectangular cells that ranged from $820 \mathrm{ft}(250 \mathrm{~m})$ to 4,921 $\mathrm{ft}(1,500 \mathrm{~m})$ on a side. Models extended vertically from the water table to 3,280 $\mathrm{ft}(1,000 \mathrm{~m})$ below sea level and were divided into six layers that successively increased in thickness with depth. Layer 1 was 1 -ft thick to better simulate groundwater and surface-water interaction, and drainage at the water table. All models have the same hydrogeologic framework of the Death Valley regional flow system (Halford and Jackson, 2019). This framework has nine hydrogeologic units that were divided primarily based on rock type and depth below the water table. Hydraulic-conductivity, specific-yield, and specific-storage distributions are identical in each calibrated model because all models shared a common hydrogeologic framework.

Hydraulic properties and recharge rates were distributed using pilot points (RamaRao and others, 1995). Hydraulic properties smoothly varied within hydrogeologic units but were not extrapolated between hydrogeologic units. Recharge similarly was distributed using pilot points, but preferred rates were guided by a conceptual model that considered water availability (precipitation) and occurrence of low-permeability rocks at the water table that likely impeded infiltration.

Hydraulic properties and recharge rates were assigned to pilot points and adjusted to minimize a weighted sum-of-squares objective function with the parameter estimation program PEST (Doherty, 2016). The following were compared to simulated equivalents in the objective function:

- Water-level altitudes in wells;

- Water-level differences between paired wells;

- Transmissivity estimates from aquifer tests;

- Spring-pool altitudes;

- Water-table altitudes in evapotranspiration areas;

- Water-table altitude comparisons to land surface;

- Drawdowns in wells during aquifer tests; and
- Water-level changes and spring capture from groundwater development.

Conceptual distributions of recharge and hydraulic properties were incorporated in the objective function through Tikhonov regularization and primarily influenced estimates where data were limited.

Groundwater-flow estimates from southern Yucca Flat were informed primarily by DV3-ER612 and DV3-SS models. The DV3-ER612 model simulated pumping during the ER-6-1-2 main MWAT and was calibrated to drawdowns in 13 observation wells (table 2). Transmissivity of the carbonate rocks beneath Yucca Flat was estimated primarily by the DV3-ER612 model. The DV3-SS model simulated predevelopment flow. Water-level altitudes in wells, water-level differences between paired wells, and transmissivity estimates from other aquifer tests constrained calibration in Yucca Flat sub-basin. Recharge and groundwater-flow estimates from the DV3-SS model were constrained regionally. This was because groundwater-discharge areas were simulated by specifying measured rates for 97 percent of total discharge.

\section{Goodness of Fit}

Simulated and measured steady-state water levels in the DV3-SS model agreed with root-mean-square errors of 49 and $20 \mathrm{ft}$ beneath the study area (fig. $4 A$ ) and Yucca Flat (fig. 4B), respectively. Water-table altitude comparisons to land surface were used to ensure that the simulated water table remained below land surface, and water-level altitudes at spring pools and in groundwater evapotranspiration areas were used to ensure that simulated water levels were at or near land surface. Water-level residuals showed little spatial pattern of significance, suggesting a good overall fit between simulated and measured water levels. Average and root-mean-square water-level errors of +1 and $49 \mathrm{ft}$, respectively, were not large relative to the 8,800 - $\mathrm{ft}$ range of measured water levels (fig. 4A). Simulated and estimated drawdowns in the DV3-ER612 model agreed with a root-mean-square error of $0.02 \mathrm{ft}$.

Simulated and measured gradients between wells ER-7-1 and ER-6-1-2 main through southern Yucca Flat closely agree (fig. 5). Simulated water-level profiles replicate the shape of the measured water table along north-south and west-east cross sections under steady-state conditions. Simulated water levels in well ER-3-1-2 (shallow) are too high because recharge was overestimated locally.

Differences between measured and simulated LCA water levels are attributed mostly to temperature effects. The measured free-water surface in the well can differ from the head in the aquifer by more than $10 \mathrm{ft}$, even though heads are identical in the well and aquifer. For example, measured water-level altitudes were 2,394 and 2,389 ft in wells ER-7-1 and $U-3 c n 5$, respectively, during 2015 . From the free-water surface to the open interval in well ER-7-1, a length of about 
Table 2. Estimated drawdowns in observation wells from ER-6-1-2 main development and testing, Ash Meadows groundwater basin, southern Nevada.

[USGS well name: U.S. Geological Survey well name. Drawdown analysis period: Start and end date of water-level record used to estimate drawdowns. Estimated maximum drawdown: Maximum water-level decline, or drawdown, in observation well from ER-6-1-2 main well development and aquifer testing A less than $(<)$ qualifier is used if drawdown was not detected or is censored. RMS error: Root-mean-square (RMS) error between measured and synthetic water levels in water-level model. A "-" indicates results not available because drawdown was not estimated with a water-level model. Signal-to-noise ratio: ratio of estimated maximum drawdown (signal) to RMS error (noise). A “-” indicates results not available because drawdown was not estimated with a waterlevel model. Drawdown detection: Drawdown detection is classified as not detected, detected, or censored. Drawdown is not detected where the signal-to-noise ratio is $<5$, indicating drawdown cannot be reliably differentiated from the noise in the dataset. Drawdown is detected definitively where the signal-to-noise ratio is $\geq 5$ and correlation between environmental fluctuations and pumping signals is unlikely. For observation wells with depth-to-water measurements, drawdown is detected if measurements show visibly discernible water-level declines during ER-6-1-2 main pumping, whereas drawdown is censored if measurements do not show visibly discernible water-level declines during ER-6-1-2 main pumping because any potential drawdown was masked by barometric pressure and tidal forces. Error bars account for $\pm 0.2 \mathrm{ft}$ water-level fluctuations from barometric pressure, tides, and measurement error]

\begin{tabular}{|c|c|c|c|c|c|}
\hline $\begin{array}{c}\text { USGS well } \\
\text { name }\end{array}$ & $\begin{array}{c}\text { Drawdown analysis } \\
\text { period }\end{array}$ & $\begin{array}{c}\text { Estimated maximum } \\
\text { drawdown (feet) }\end{array}$ & $\begin{array}{c}\text { RMS error } \\
\text { (feet) }\end{array}$ & $\begin{array}{c}\text { Signal-to-noise } \\
\text { ratio }\end{array}$ & $\begin{array}{c}\text { Drawdown } \\
\text { detection }\end{array}$ \\
\hline \multicolumn{6}{|c|}{ Observation wells-Drawdown estimated from continuous water-level data and water-level model } \\
\hline ER-6-1 main (lower zone) & March 18-November 3, 2004 & 2.11 & 0.08 & 26 & Detected \\
\hline $\begin{array}{l}\text { ER-6-1 main } \\
\quad \text { (upper zone) }\end{array}$ & March 18-November 3, 2004 & 2.25 & 0.05 & 44 & Detected \\
\hline ER-6-1-2 piezometer & March 18-November 3, 2004 & $<0.05$ & 0.05 & 1 & Not detected \\
\hline$E R-7-1$ & March 18-November 3, 2004 & 1.75 & 0.06 & 28 & Detected \\
\hline Tracer Well $3(A D-6)^{1}$ & March 15, 2003-December 15, 2005 & 0.08 & 0.01 & 7 & Detected \\
\hline$U E-1 h$ & March 18-November 3, 2004 & $<0.04$ & 0.01 & 3 & Not detected \\
\hline$U E-7 n S$ & November 1, 2003-December 1, 2004 & $1.2+0.2$ & - & - & Detected \\
\hline$U E-10 j(2232-2297 f t)$ & November 1, 2003-December 1, 2004 & $<0.4+0.2$ & - & - & Censored \\
\hline$W W-2(3422 f t)$ & November 1, 2003-December 1, 2004 & $<0.7+0.2$ & - & - & Censored \\
\hline
\end{tabular}

${ }^{1}$ Water levels affected by pumping in wells Army $1 \mathrm{WW}$ and ER-6-1-2 main.

$620 \mathrm{ft}$, the water temperature is about $115^{\circ} \mathrm{F}$, indicating that the head is minimally affected by temperature. However, temperatures along a 1,400-ft water column in well $U-3 c n$ 5 ranged from $91^{\circ} \mathrm{F}$ at the free-water surface to $154^{\circ} \mathrm{F}$ in the interval open to the LCA. Measured water levels in well $U-3$ cn 5 would be $12 \mathrm{ft}$ higher if the temperature of the 1,400-ft water column was uniform and at formation temperature $\left(154^{\circ} \mathrm{F}\right)$. These are substantial differences that were addressed by acknowledging uncertainty in uncorrected water levels. Formal corrections were not attempted because intervening distributions of hydraulic conductivity and temperature between wells are unknown. In Yucca Flat, relatively cool water columns are present in the casing of LCA wells that penetrate greater than $1,000 \mathrm{ft}$ of TCU. Free-water surface temperatures range from 66 to $122^{\circ} \mathrm{F}$ and are lowest where the TCU is thickest in central Yucca Flat $\left(19-50{ }^{\circ} \mathrm{C}\right.$; Navarro-Intera, LLC, 2013).

\section{Flow Computation Approaches}

Groundwater-flow rates from southern Yucca Flat were estimated between wells ER-7-1 and ER-6-1-2 main because all flow through nuclear testing areas passes between these wells (fig. 2). A southern boundary (between wells ER-7-1 and ER-6-1-2 main) was delineated (fig. 6) using the simulated water-table from the DV3-SS model, steady-state flow paths, a simulated transmissivity map, and estimated drawdowns at observation wells (Halford and Jackson, 2019). The southern boundary is perpendicular to simulated water-table contours and steady-state flow paths (fig. 6). Note that wells ER-7-1 and ER-6-1-2 main occur in a high-transmissivity corridor in east-central Yucca Flat that is bounded on the east and west by low-transmissivity rocks. Because transmissivity is correlated to groundwater flow, a high-transmissivity corridor 


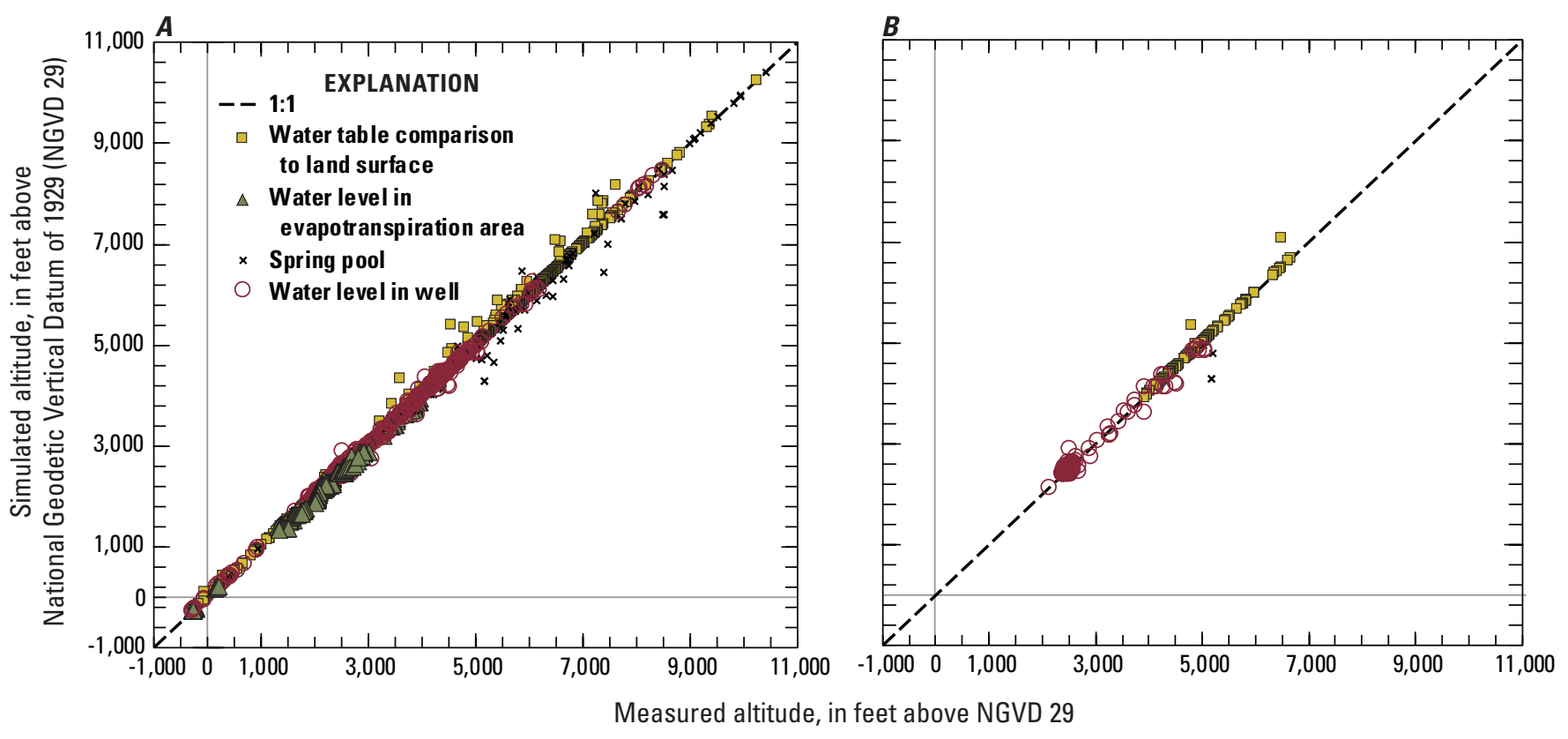

Figure 4. Comparison of measured and simulated altitudes of $(A)$ all observations used in the Death Valley (version 3) steady-state model (DV3-SS), and ( $B$ ) observations in Yucca Flat sub-basin, southern Nevada.

bounded by low-transmissivity rocks indicates that most groundwater flowing south from Yucca Flat passes through this high-transmissivity corridor.

The groundwater-flow rate from southern Yucca Flat was estimated directly using the DV3-SS model and indirectly from transmissivity-width products calculated over an area of high transmissivity between wells ER-7-1 and ER-6-1-2 main (fig. 6). Simulated flow rates from Yucca Flat were extracted from the DV3-SS model with the direct approach using Zone Budget, a MODFLOW groundwater utility (Harbaugh, 1990). The transmissivity-width approach estimates flow across southern Yucca Flat using Darcy's Law and a simulated transmissivity map. The use of alternative approaches indicates the range in uncertainty of groundwater-flow rates from Yucca Flat.

In the transmissivity-width approach, the groundwater-flow rate was computed as the product of transmissivity, aquifer width, and horizontal hydraulic gradient between wells ER-7-1 and ER-6-1-2 main. The horizontal hydraulic gradient was the difference between average measured heads in wells ER-7-1 and ER-6-1-2 main. More than 40 water-level measurements were averaged from 2005 to 2015 in each well. Heads consistently differed by $2.6 \mathrm{ft}$ between these wells and the hydraulic gradient was $0.42 \mathrm{ft} /$ mi. Aquifer width is the east-west width of the transmissive corridor. Groundwater-flow rates from southern Yucca Flat were computed using the geometric mean (eq. 1) and harmonic mean (eq. 2) of transmissivity-width products:

$$
Q_{\text {geom }}=\frac{\Delta h}{\Delta L} \times\left(\prod_{j=1}^{n}\left[\sum_{i=1}^{m} T \Delta x_{i}\right]_{j}\right)^{1 / n}
$$

$$
Q_{\text {harm }}=\frac{\Delta h}{\Delta L} \times \frac{\sum_{j=1}^{n} \Delta y_{j}}{\sum_{j=1}^{n}\left[\frac{\Delta y_{j}}{\sum_{i=1}^{m} T \Delta x_{i}}\right]},
$$

where

$Q_{\text {geom }}$ and $Q_{\text {harm }}$ are estimates of groundwater-flow rates computed using the geometric and harmonic means, respectively, of transmissivity-width products, in foot cubed per day;

$T$ is transmissivity, in feet squared per day;

$\Delta x$ and $\Delta y \quad$ are grid cell widths and heights, respectively; $i$ and $j \quad$ are summation indices in the $\mathrm{x}$ and $\mathrm{y}$ directions, respectively;

$m$ and $n \quad$ are the number of columns (x-direction) and rows (y-direction), respectively, used to compute transmissivity-width products; and 
$\Delta h / \Delta L \quad$ is the horizontal hydraulic gradient, in foot per foot $(\mathrm{ft} / \mathrm{ft})[0.42$ foot per mile $=$ $0.00008 \mathrm{ft} / \mathrm{ft}]$.

The area for computing transmissivity-width products shown in fig. 6 spans 15 columns $(m)$ and 14 rows $(n)$, where transmissivity-width products were summed along each column and averaged across all rows.

\section{Hydraulic Responses from ER-6-1-2 Main Multiple-Well Aquifer Test}

Drawdowns in observation wells were estimated from continuous water-level data and manual depth-to-water measurements. Continuous water-level data in eight observation wells were analyzed for drawdowns using WLMs. WLM analyses showing fitting parameters, measured and synthetic water levels, and drawdown estimates for the eight analyzed wells (table 1) are provided in a corresponding data release (Jackson and others, 2019). Seven of the eight

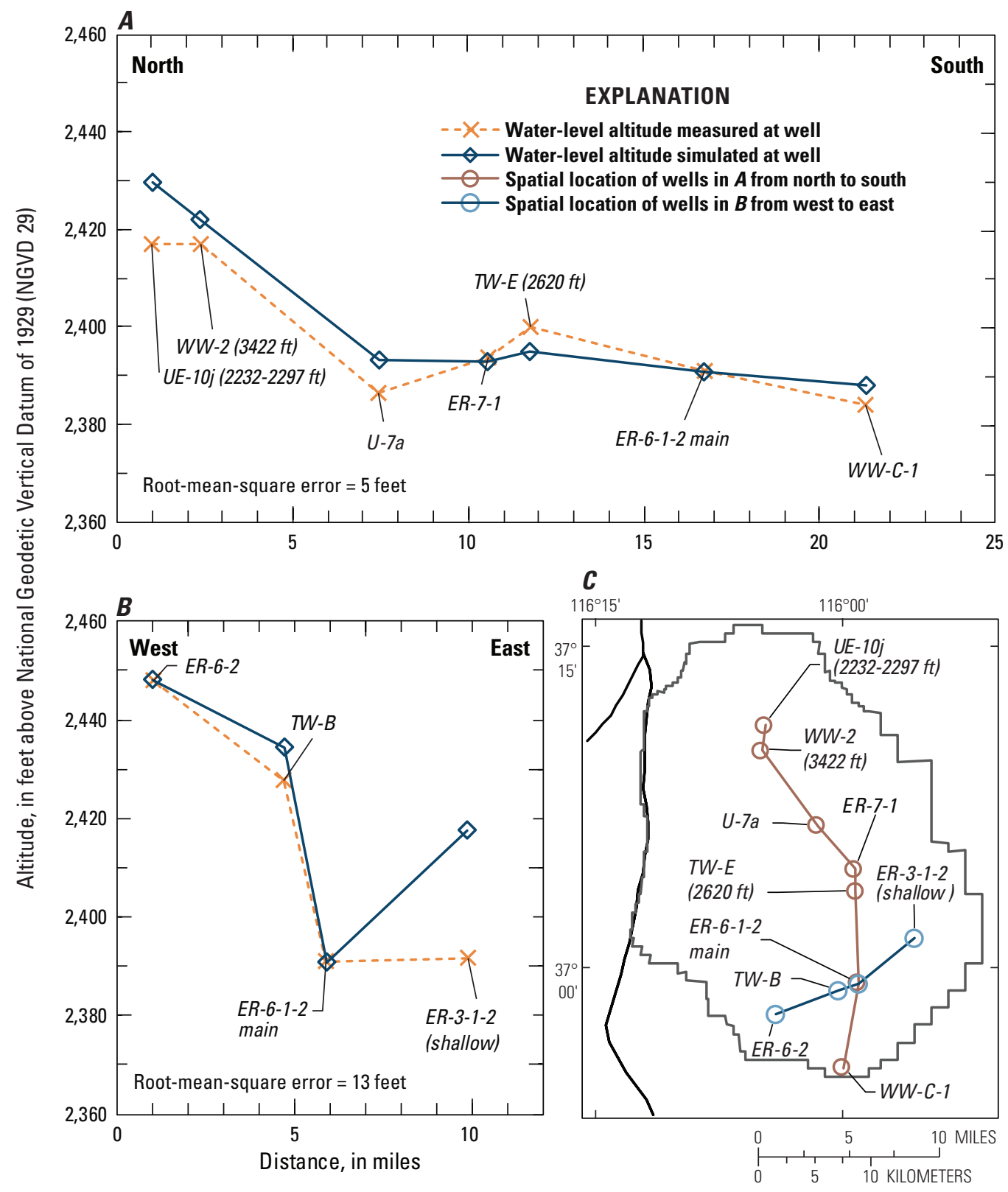

Figure 5. Comparison of measured and simulated water-level altitudes of wells extending $(A)$ northsouth and $(B)$ west-east across Yucca Flat sub-basin, and $(C)$ spatial locations of these wells in Yucca Flat sub-basin, southern Nevada. 


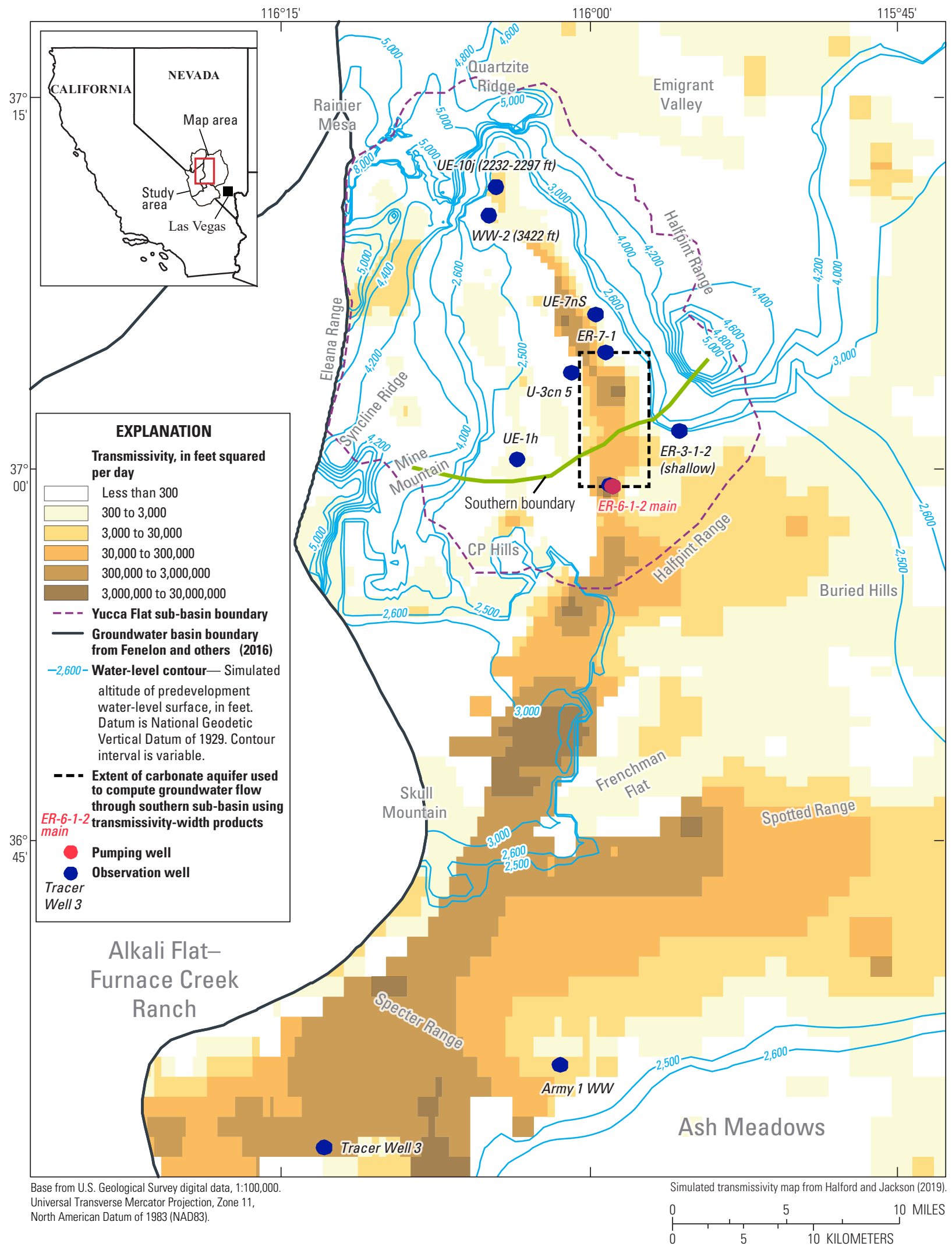

Figure 6. Pumping and observation wells, simulated water-level contours and transmissivity, and physiographic features, Yucca Flat sub-basin and vicinity, southern Nevada. 
observation wells are in Yucca Flat and one observation well is downgradient of Yucca Flat. Manual, depth-to-water measurements were used to evaluate drawdowns in five observation wells.

\section{Observation Wells with Continuous Water-Level Data}

Continuous water-level data were analyzed from March 18, 2004, to November 3, 2004, to estimate drawdowns in seven Yucca Flat observation wells monitored before, during, and after the 90-day constant-rate test. Drawdowns were not analyzed prior to the 90-day constant-rate test because sufficient data were not available. Synthetic water levels matched measured water levels, with root-mean-square errors ranging from 0.01 to $0.08 \mathrm{ft}$ in observation wells (table 2; Jackson and others, 2019).

Estimated drawdowns were classified as either detected or not detected (fig. 7; table 2). Drawdowns were detected in five Yucca Flat observation wells: ER-3-1-2 (shallow), ER-6-1 main (lower zone), ER-6-1 main (upper zone), ER-6-1-1, and $E R-7-1$ (fig. 7A-7E). Drawdowns were not detected in two Yucca Flat wells: ER-6-1-2 piezometer and UE-1h (fig. $7 F-7 G$ ).

Water levels in Tracer Well 3 were affected by pumping from wells Army $1 W W$ and ER-6-1-2 main during the MWAT. Effects of pumping on water levels in Tracer Well 3 were determined by comparing WLMs that either excluded or included pumping from wells Army $1 W W$ and ER-6-1-2 main. Water levels were modeled initially using only environmental fluctuations from barometric pressure and tides, and measured water levels were explained poorly (fig. 8A). WLM results show a deviation in residuals of about $0.09 \mathrm{ft}$ from March to October 2004. This deviation in residuals indicates that one or more aquifer stresses were not accounted for in the WLM. From March to October 2004, both short-term and long-term pumping was occurring in the LCA. Well Army $1 \mathrm{WW}$, which is open to the LCA, was pumped from 1960 to 2014 for water supply on the NNSS. When long-term pumping from Army $1 W W$ and pumping from the ER-6-1-2 main MWAT were included in the WLM, deviations in the residuals were small (less than $0.02 \mathrm{ft}$; fig. $8 B$ ). Maximum estimated drawdown in Tracer Well 3 was about $0.10 \mathrm{ft}$ from both Army $1 \mathrm{WW}$ and ER-6-1-2 main pumping, where most (about $0.08 \mathrm{ft}$ ) of the drawdown resulted from the ER-6-1-2 main MWAT (fig. 8C).

\section{Observation Wells with Manual Measurements}

Manual, depth-to-water measurements in five observation wells were analyzed from November 2003 to December 2004 to estimate drawdowns from pumping during the ER-6-1-2 main MWAT. Maximum estimated drawdowns do not necessarily coincide with peak drawdowns at these wells because manual measurements were made periodically at intervals of 5-117 days. Drawdowns were detected if measurements showed visibly discernible water-level declines during ER-6-1-2 main pumping. Drawdowns were censored if measurements did not show visibly discernible water-level declines during ER-6-1-2 main pumping because any potential drawdown was masked by barometric pressure and tidal forces.

Pumping in well Army $1 \mathrm{WW}$ from April 2001 to October 2005 caused water levels to decline by about $6 \mathrm{ft}$ (fig. 9A). Part of this water-level decline in Army $1 \mathrm{WW}$ may be attributed to pumping well ER-6-1-2 main during the MWAT because: (1) drawdowns were detected in Tracer Well 3; (2) Army $1 \mathrm{WW}$ is between pumping well ER-6-1-2 main and Tracer Well 3; and (3) wells ER-6-1-2 main, Army $1 \mathrm{WW}$, and Tracer Well 3 are open to the LCA.

Drawdowns in well Army $1 \mathrm{WW}$ were estimated from depth-to-water measurements from February 23 to December 13, 2004 (fig. 9A). Maximum drawdown during this period was about $0.8 \pm 0.2 \mathrm{ft}$ (fig. $9 B$, table 2 ), where most of the estimated drawdown was attributed to pumping in well Army $1 \mathrm{WW}$. Therefore, estimated drawdown in well Army 1 $W W$ from pumping in ER-6-1-2 main were censored, where drawdowns induced by the MWAT are from 0 to $0.1 \mathrm{ft}$.

Depth-to-water measurements in wells $U-3 c n 5$ and $U E-7 n S$ showed observable water-level declines from pumping during the ER-6-1-2 main MWAT (fig. $9 C$ and $9 E$ ). A maximum drawdown of about $2.3 \pm 0.2 \mathrm{ft}$ was estimated in well $U$-3cn 5 from November 17, 2003 to November 2, 2004 (fig. 9D; table 2). A maximum drawdown of about $1.2 \pm 0.2 \mathrm{ft}$ was estimated in well $U E-7 n S$ from April 7 to November 10, 2004 (fig. 9F; table 2).

Water levels in wells $U E-10 j(2232-2297 f t)$ and $W W-2$ (3422 ft) likely were affected by pumping, but drawdowns were not detectable during the ER-6-1-2 main MWAT. Water levels likely were affected by the ER-6-1-2 main MWAT because maximum drawdowns of 0.04 and $0.02 \mathrm{ft}$ were detected in wells $U E-10 j(2232-2297 \mathrm{ft})$ and $W W-2$ $(3422 \mathrm{ft}$ ), respectively, during the $E R-4-1 \mathrm{~m} 1$ MWAT from February 7 to 17, 2017 (Jackson, 2017). Less than 2 Mgal were pumped during the ER-4-1 $\mathrm{ml}$ MWAT or about 3 percent of the volume pumped during the ER-6-1-2 main MWAT. Infrequent measurements and water-level fluctuations of \pm 0.2 $\mathrm{ft}$ from barometric pressure and tides likely masked potential drawdowns in wells $U E-10 j(2232-2297 \mathrm{ft})$ and $W W-2(3422$ ft) during the ER-6-1-2 main MWAT (fig. 9G-J).

\section{Hydraulic Connections in Lower Carbonate Aquifer}

Hydraulic connections in the LCA were determined from a simulated transmissivity map and drawdowns from ER-6-1-2 main pumping. Between Yucca Flat sub-basin and Ash Meadows discharge area, estimated transmissivities are 

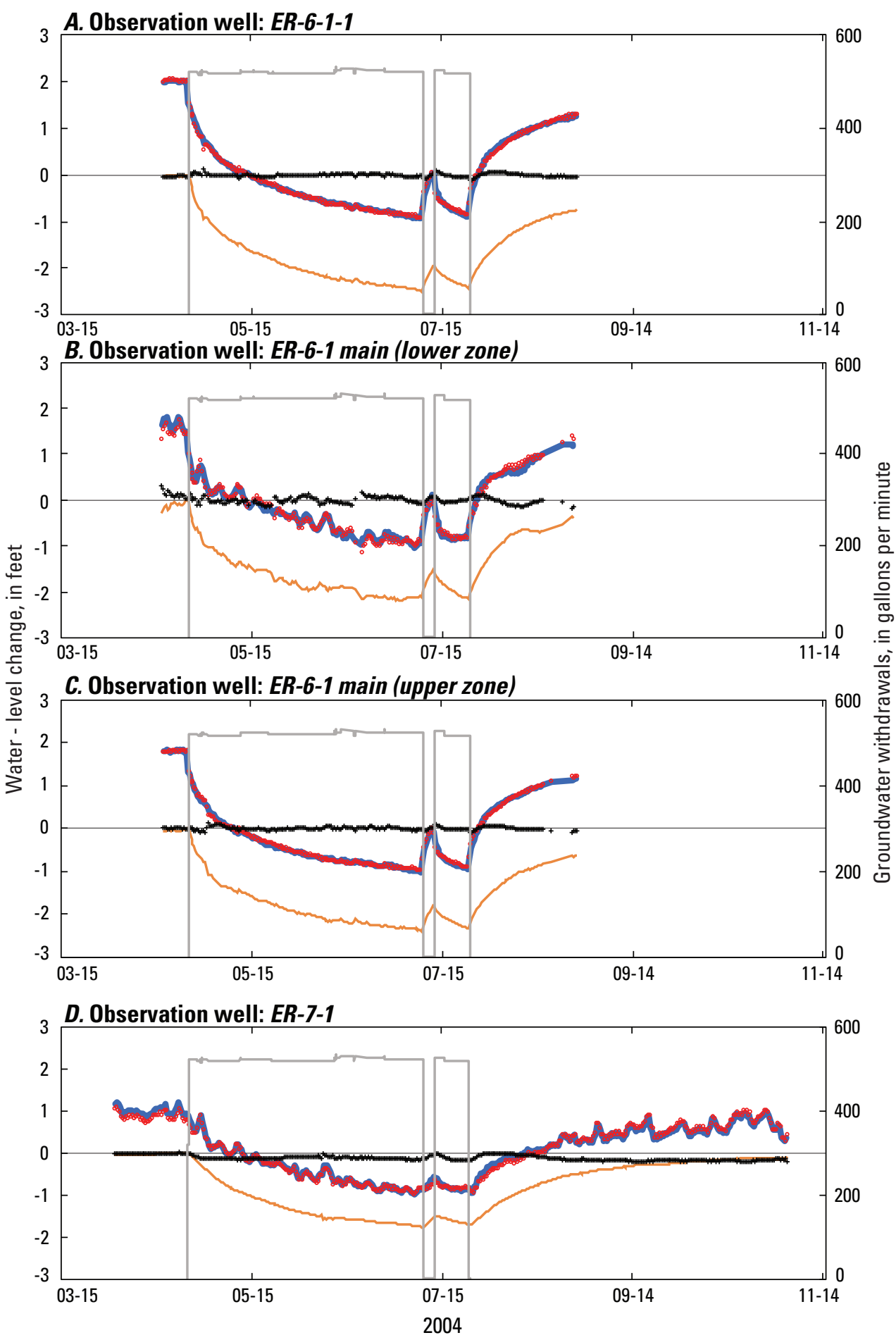

EXPLANATION

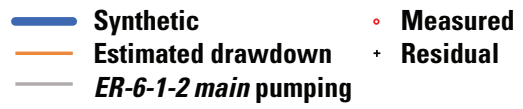

Figure 7. Estimated drawdown analysis results for wells $(A)$ ER-6-1-1, (B) ER-6-1 main (lower zone), (C) ER-6-1 main (upper zone), (D) ER-7-1, (E) ER-3-1-2 (shallow), (F) ER-6-1-2 piezometer, and $(G) U E-1 h$, Yucca Flat sub-basin, southern Nevada. Measured and synthetic water levels are shifted above the $\mathrm{x}$-axis to clearly display all data on plots. 
E. Observation well: ER-3-1-2 (shallow)
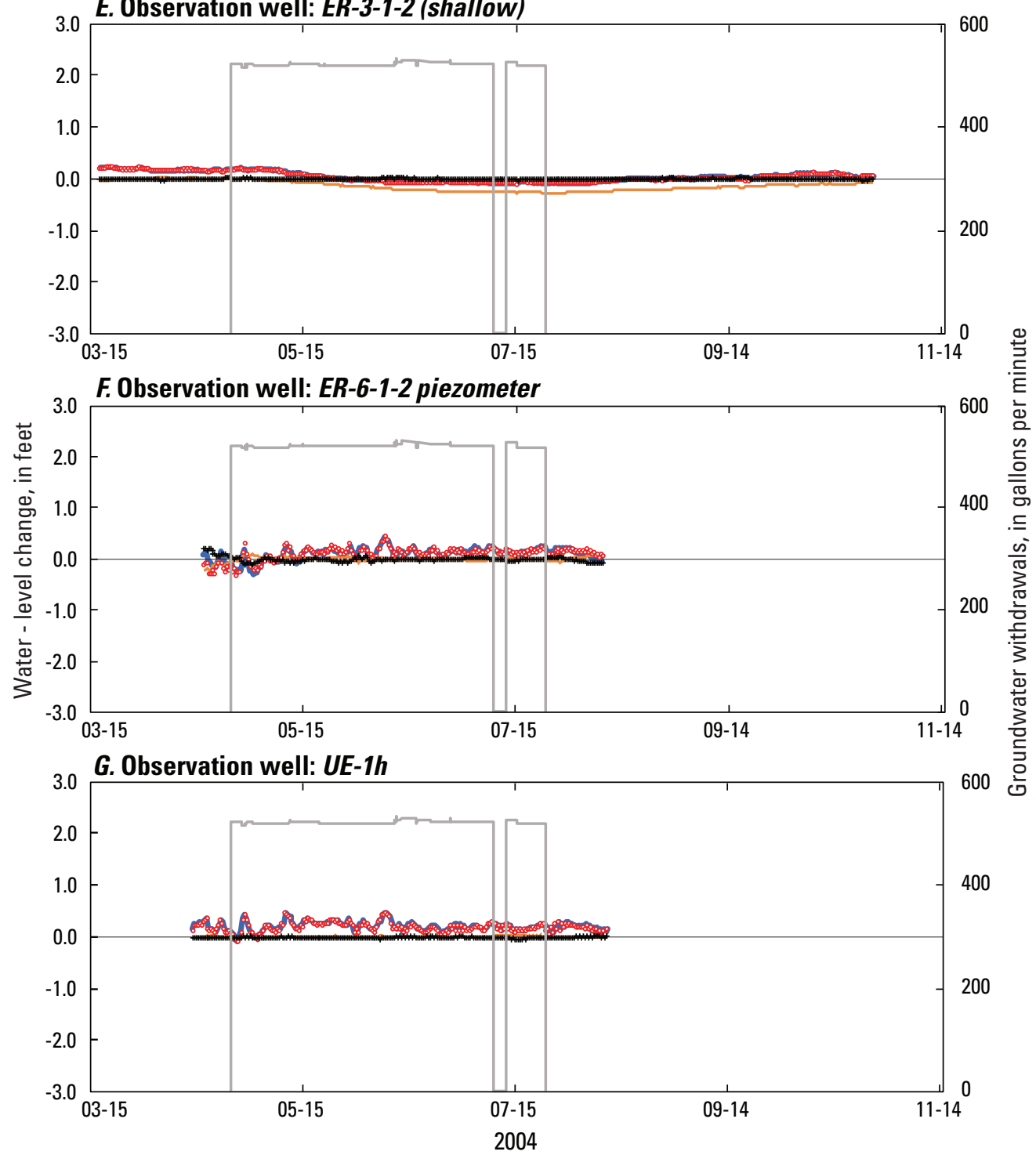

EXPLANATION

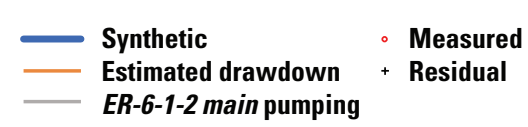

Figure 7. - Continued

plausible because data are available between these locations and numerical model results agree with observations.

Simulated steady-state water levels, spring discharges, and drawdowns replicate observed conditions, which is a measure of agreement.

Simulated drawdowns from the DV3-ER612 model match estimated drawdowns within the limits of estimate uncertainty (figs. 10-12). The pumping history from well Army $1 \mathrm{WW}$ was not simulated in the DV3-ER612 model; therefore, simulated drawdowns only account for the effects of pumping from ER-6-1-2 main. Wells ER-6-1-1, ER-6-1 main (lower zone), and ER-6-1 main (upper zone) have similar drawdowns because these observation wells are within 300 $\mathrm{ft}$ of the pumping well (fig. $10 B-D$ ). Simulated drawdowns compare more favorably with drawdowns estimated from continuous data (fig. 10), compared to drawdowns estimated from depth-to-water measurements, because measurement uncertainties in continuous data are less than uncertainties from barometric pressure and tides in depth-to-water measurements (fig. 11).

Drawdowns were not detected in western Yucca Flat. Drawdowns were not detected $(<0.04 \mathrm{ft})$ from measured data in well $U E-1 h$ during the ER-6-1-2 main MWAT (fig. 7G; table 2). Consistent with this observation, no drawdown was 

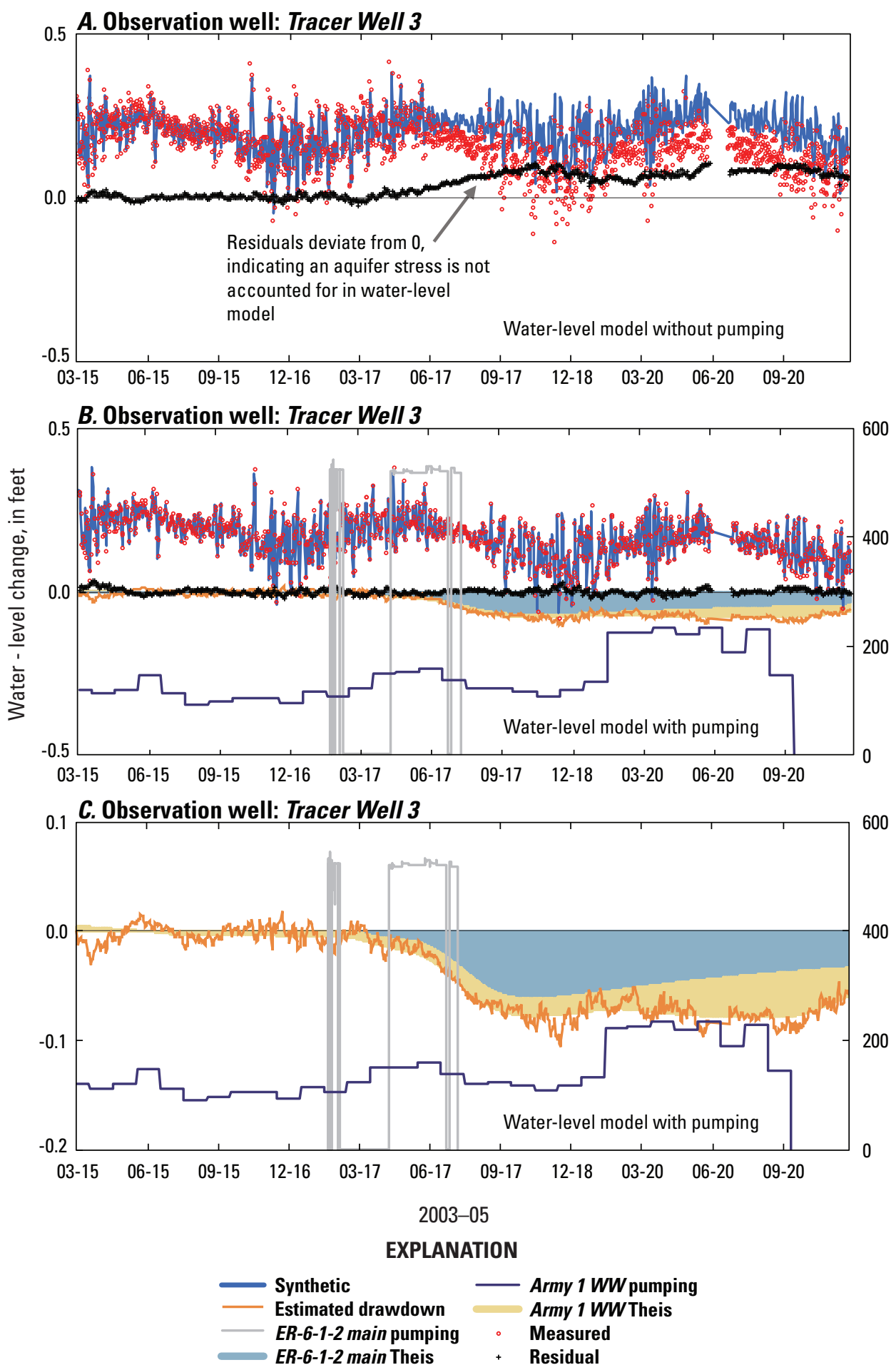

Figure 8. Estimated drawdown analysis results for Tracer Well 3, Ash Meadows groundwater basin, southern Nevada, 2003-05. A, Estimated drawdown results using a water-level model that does not include pumping from wells ER-6-1-2 main and Army 1 WW. B, Estimated drawdown results using a water-level model that includes pumping from wells ER-6-1-2 main and Army 1 WW. C, Total estimated drawdown and two components of drawdown, Theis transform of ER-6-1-2 main pumping, and Theis transform of Army 1 WW pumping. 


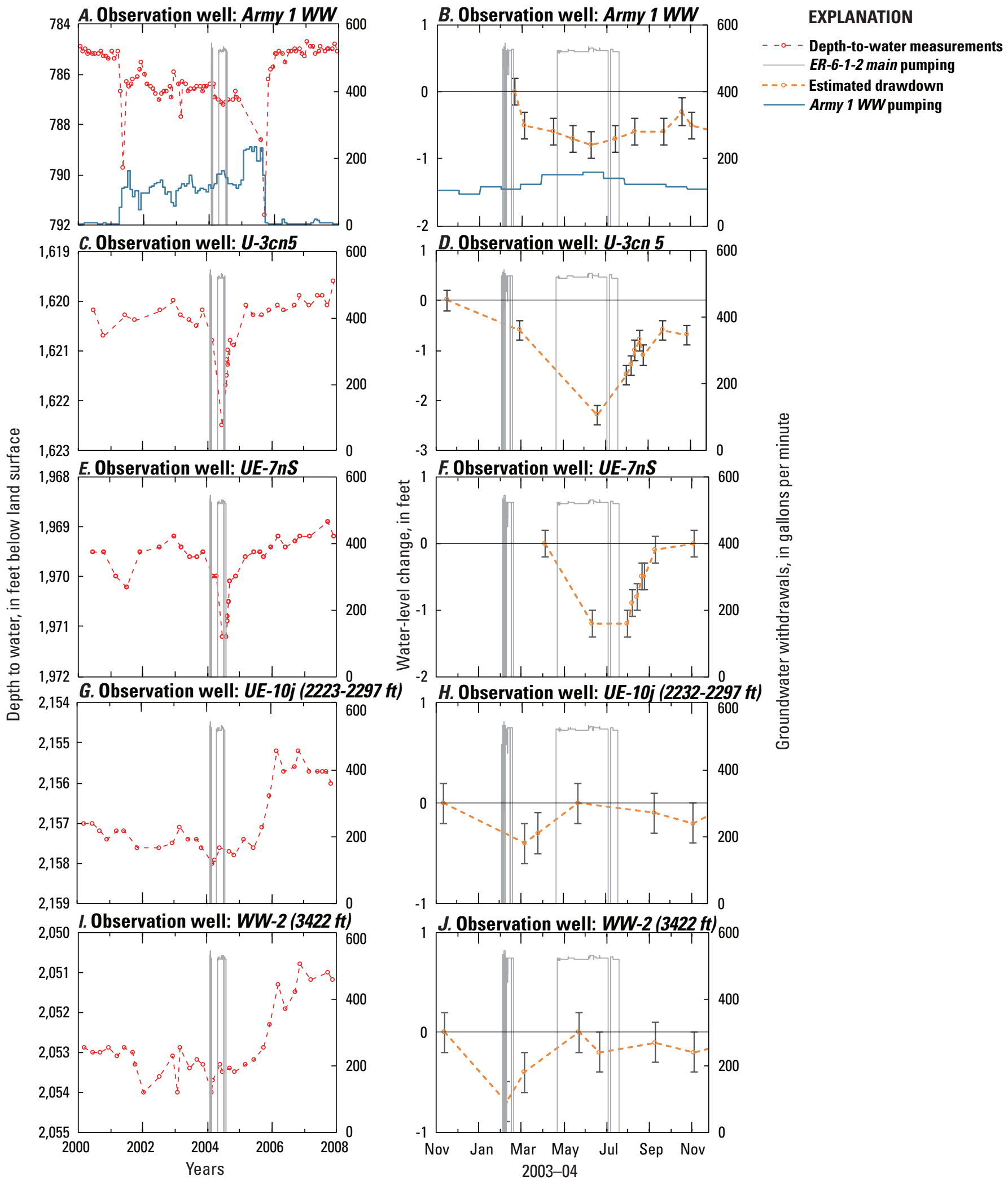

Figure 9. Graphs showing depth-to-water measurements and water-level change (estimated drawdowns) in wells Army 1 WW, U-3cn 5, UE-7nS, UE-10j (2232-2297 ft), and WW-2 (3422 ft), and groundwater withdrawals in wells ER-6-1-2 main and Army 1 WW, Yucca Flat sub-basin and vicinity, southern Nevada, 2000-08 (for depth-to-water-measurements) and 2003-04 (for drawdowns). Error bars account for \pm 0.2-foot water-level fluctuations resulting from barometric pressure, tides, and measurement error. 

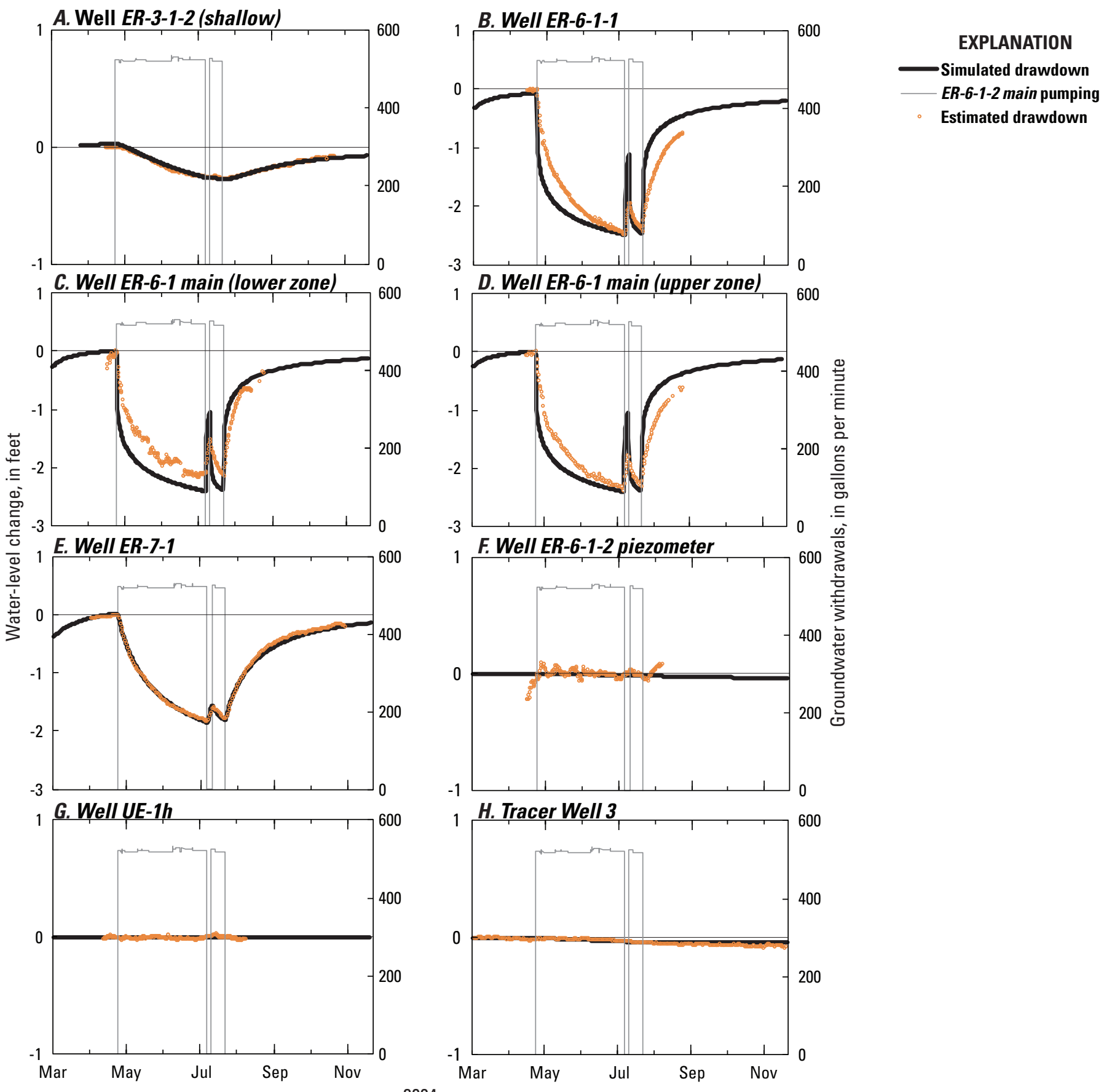

Figure 10. Estimated and simulated drawdowns in observation wells continuously monitored for the ER-6-1-2 main multiple-well aquifer test, Yucca Flat sub-basin and vicinity, southern Nevada. Simulated drawdowns are from the Death Valley (version 3) transient model of ER-6-1-2 main multiple-well aquifer test (DV3-ER612). 

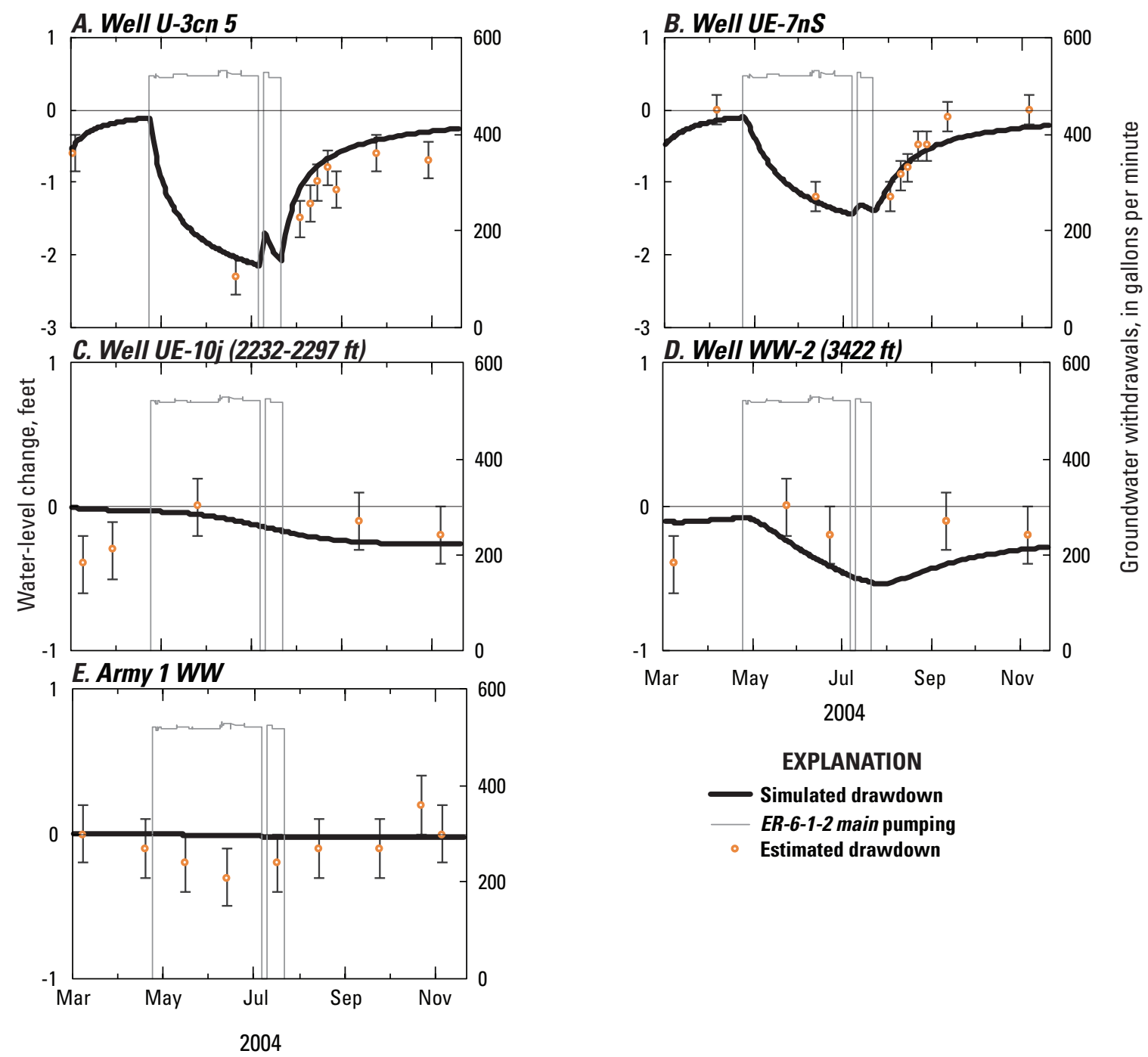

Figure 11. Estimated and simulated drawdowns in observation wells measured periodically during the ER-6-1-2 main multiple-well aquifer test, Yucca Flat sub-basin and vicinity, southern Nevada. Simulated drawdowns are from the Death Valley (version 3) transient model of ER-6-1-2 main multiple-well aquifer test (DV3-ER612). Error bars on estimated drawdowns account for \pm 0 .2-foot water-level fluctuations from barometric pressure, tides, and measurement error.

simulated in the DV3-ER612 model (fig. 10G). Drawdown also was not detected $(<0.01 \mathrm{ft})$ from measured data in well $U E-1 h$ and four other observation wells in western Yucca Flat during the ER-4-1 $m 1$ MWAT (Jackson, 2017).

Simulated drawdowns in wells $U E-10 j(2232-2297$ $f t)$ and $W W-2(3422 \mathrm{ft})$ were consistent with the limited available drawdown estimates for these wells during the ER-6-1-2 main MWAT (fig. 11C-D) and with results from the ER-4-1 $m 1$ MWAT. Simulated drawdowns of less than $0.5 \mathrm{ft}$ are less than maximum estimated drawdowns of 0.6 and $0.9 \mathrm{ft}$ in wells $U E-10 j(2232-2297 \mathrm{ft})$ and $W W-2(3422$ $f t$ ), respectively (table 2). Simulated drawdowns in wells $U E-10 j(2232-2297 f t)$ and $W W-2(3422 f t)$ are proportionately greater than estimated drawdowns from the ER-4-1 ml MWAT (Jackson, 2017).
The high-transmissivity corridor in east-central Yucca Flat sub-basin extends to the Ash Meadows discharge area (fig. 1). The DV3-ER612 model simulated maximum drawdowns of $0.03 \mathrm{ft}$ in well Army $1 \mathrm{WW}$ (fig. 11E) and 0.04 $\mathrm{ft}$ in Tracer Well 3 (fig. 12), indicating that the LCA in Yucca Flat is hydraulically connected to LCA more than $30 \mathrm{mi}$ south-southwest of Yucca Flat. Simulated transmissivities in the high-transmissivity corridor extending from Yucca Flat to the Ash Meadows discharge area exceed 300,000 ft²/d (fig. 6). This high-transmissivity corridor was delineated based on steady-state water levels, discharges, and aquifer-test results. High transmissivity near the Ash Meadows discharge area has been known since the 1970s based on single-well aquifer-test results and flow paths determined from head differences and geochemical studies. Winograd and Pearson (1976) referred to 


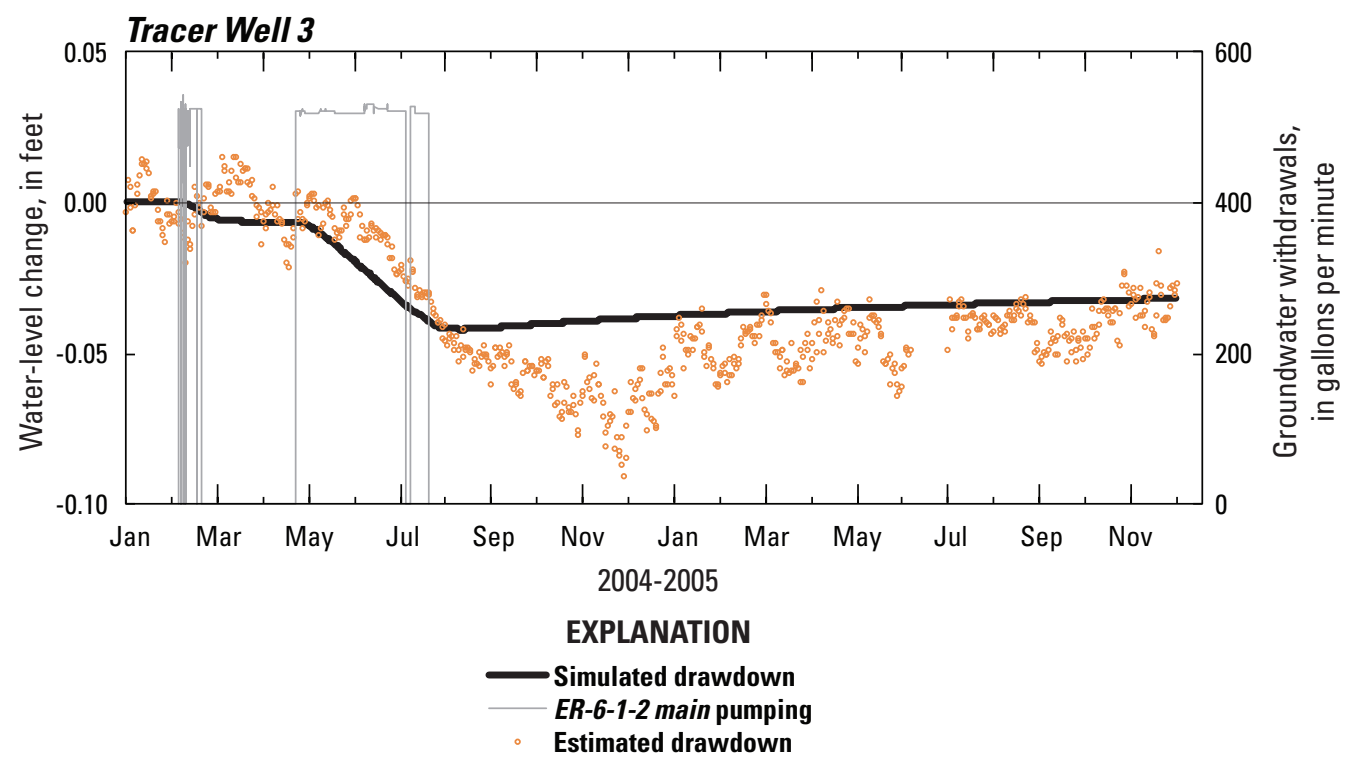

Figure 12. Estimated and simulated drawdowns in Tracer Well 3 continuously monitored for the ER-6-1-2 main multiple-well aquifer test, Yucca Flat sub-basin and vicinity, southern Nevada. Simulated drawdowns are from the Death Valley (version 3) transient model of ER-6-1-2 main multiple-well aquifer test (DV3-ER612).

the high-transmissivity region near Ash Meadows discharge area as a "megachannel," and ER-6-1-2 main MWAT results indicate that the northern extent of the megachannel occurs near well $U E-10 j(2232-2297 \mathrm{ft})$.

\section{Yucca Flat Boundary Flow}

Delineation of the southern Yucca Flat boundary between wells ER-7-1 and ER-6-1-2 main (fig. 6) is consistent with drawdown results. Drawdowns in observation wells ER-7-1, ER-3-1-2 (shallow), and UE-1h during the ER-6-1-2 main MWAT are consistent with a north-south trending corridor of transmissive carbonate rocks that are bounded on the east and west by low-transmissivity rocks. A maximum drawdown of $1.75 \mathrm{ft}$ was estimated in well $E R-7-1$ with little attenuation or delay 6 mi north of well ER-6-1-2 main (table 2; fig. 7D). Maximum drawdown was limited to less than $0.33 \mathrm{ft}$ in well ER-3-1-2 (shallow) 4 mi northeast of well ER-6-1-2 main (table 2; fig. 7E). Water levels in well $U E$ - $1 h$ were unaffected by the pumping of $75 \mathrm{Mgal}$ from well ER-6-1-2 main about 4 mi east (fig. $7 G$ ).

The groundwater-flow rate from Yucca Flat was estimated previously near well $W W-C-1$ (fig. 1; Navarro-Intera, LLC, 2013). This location is at the southern extent of Yucca Flat sub-basin but is not well-suited for use as a control volume for flow from Yucca Flat. This is because 3,700 acre-ft/yr flows past well $W W-C-1$, but less than 600 acre-ft/yr passes through the nuclear testing area north of well ER-7-1 (fig. 13). Significant flow moving southwest through the Halfpint Range to well $W W-C-1$ is consistent with geochemical modeling and carbon dating (Navarro-Intera, LLC, 2013)

Groundwater-flow rates downgradient of underground nuclear testing areas range from 530 to 1,100 acre-ft/yr. The DV3-SS model simulated 530 acre-ft/yr flowing through the transmissive corridor midway between wells $E R-7-1$ and ER-6-1-2 main. Simulated water levels in wells ER-7-1 and ER-6-1-2 main differed by $2.4 \mathrm{ft}$ or 93 percent of the measured head difference. Groundwater-flow rates through the transmissive corridor ranged from 660 to 1,100 acre-ft/ yr using harmonic and geometric mean transmissivity-width products, respectively. These estimates were biased higher than estimates from the DV3-SS model because the transmissivity-width product assumed a uniform horizontal hydraulic gradient and perpendicular (north-south) flow for each (east-west) model row used to compute the flow rate. This approach does not account for additional head losses where strong transmissivity contrasts occur in individual model columns. Based on these analyses and their associated uncertainty, less than $600 \mathrm{acre}-\mathrm{ft} / \mathrm{yr}$ likely flows through the transmissive corridor downgradient of underground nuclear testing areas in Yucca Flat and this flow likely originates from contributing areas that extend from Rainier Mesa to the west, the Halfpint Range to the east, and north of Quartzite Ridge (fig. 13). 


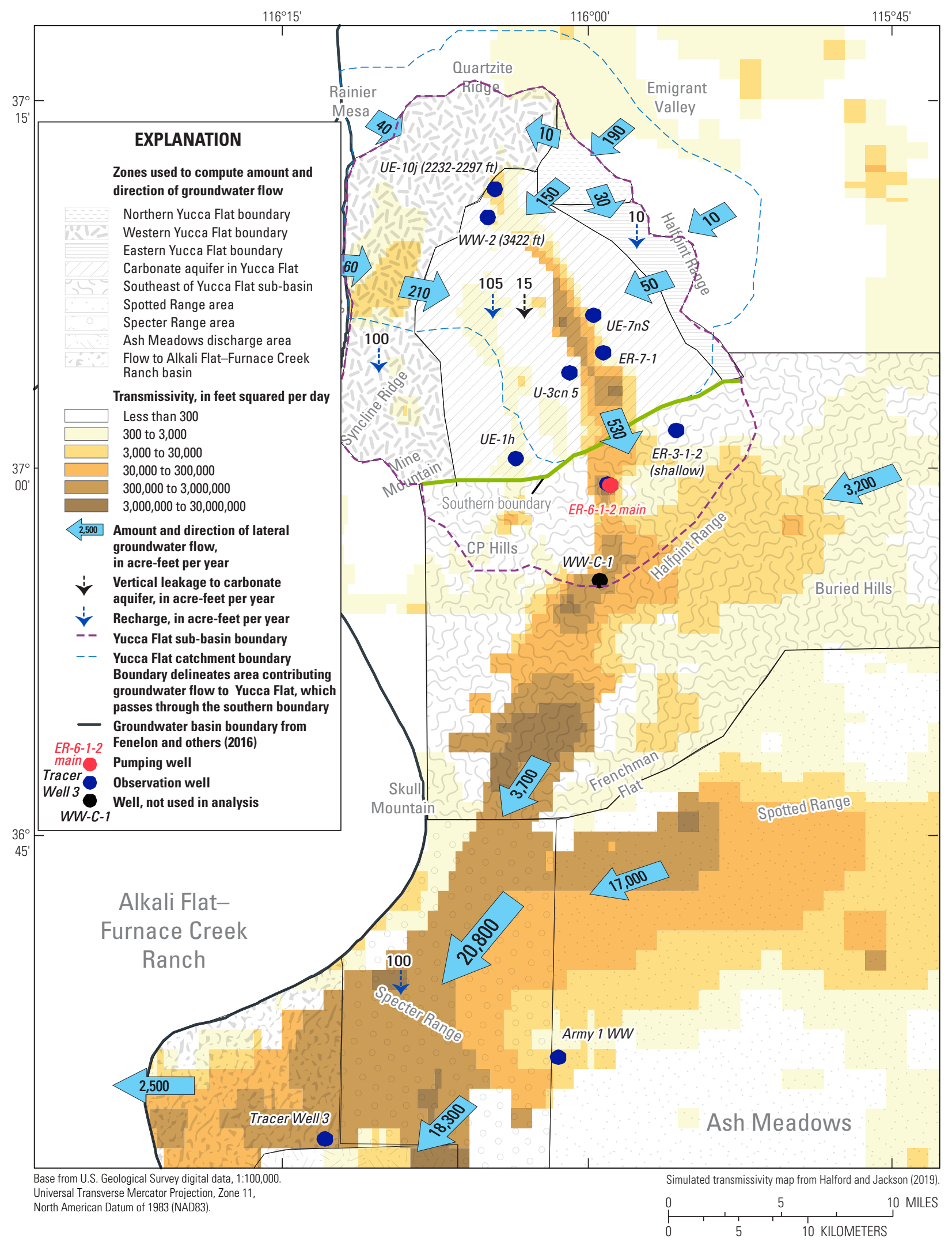

Figure 13. Physiographic features, pumping and observation wells, and simulated transmissivity and groundwater flow, Yucca Flat sub-basin and vicinity, southern Nevada. 


\section{Summary and Conclusions}

The purpose of this study is to estimate the groundwater-flow rate from southern Yucca Flat at the Nevada National Security Site, southern Nevada, using results from the ER-6-1-2 main multiple-well aquifer test (MWAT), done during February 5-July 23, 2004. Water-level drawdowns associated with pumping from well ER-6-1-2 main were evaluated for 13 observation wells. Horizontal distances between pumping and observation wells ranged from 0 to 33 miles (mi). The drawdowns were used as observations in a regional groundwater-flow model to estimate the flow rate from Yucca Flat.

Continuous water-level data were analyzed with water-level models to estimate drawdowns in eight observation wells from pumping during the ER-6-1-2 main MWAT. Drawdowns were detected in six observation wells: ER-3-1-2 (shallow), ER-6-1 main (lower zone), ER-6-1 main (upper zone), ER-6-1-1, ER-7-1, and Tracer Well 3. Drawdowns were not detected in the remaining two observation wells: ER-6-1-2 piezometer and UE-1h.

Depth-to-water measurements were used to evaluate drawdowns in five observation wells, where discrete measurements were made at approximate weekly-to-quarterly intervals. Drawdowns of more than 1 foot $(\mathrm{ft})$ were detected in wells $U-3 c n 5$ and $U E-7 n S$ from pumping during the ER-6-1-2 main MWAT. Environmental water-level fluctuations, predominantly barometric pressure and tides, masked drawdowns in wells $U E-10 j(2232-2297 \mathrm{ft})$ and $W W-2(3422$ $f t$ ). Water levels in well Army $1 \mathrm{WW}$ were affected by pumping from Army $1 W W$ and ER-6-1-2 main, and numerical results indicated that a maximum drawdown of $0.03 \mathrm{ft}$ in Army $1 \mathrm{WW}$ was induced from pumping during the ER-6-1-2 main MWAT.

Estimated drawdowns in observation wells were used to evaluate hydraulic connections within and downgradient of Yucca Flat sub-basin. Water levels in well $U E-1 h$ were unaffected by pumping during the ER-6-1-2 main MWAT, indicating that pumping did not propagate into western Yucca Flat. Simulated drawdowns of less than $0.5 \mathrm{ft}$ occurred in wells $U E-10 j(2232-2297 f t)$ and $W W-2(3422 f t)$, showing that pumping propagated more than $14 \mathrm{mi}$ into northern Yucca Flat. Pumping in ER-6-1-2 main induced drawdowns downgradient in wells Army $1 \mathrm{WW}$ and Tracer Well 3, indicating that pumping propagated at least $33 \mathrm{mi}$ to the southwest near the Ash Meadows discharge area. These drawdown results indicate that a high transmissivity corridor extends from well $U E-10 j$ (2232-2297 ft) in northern Yucca Flat to the Ash Meadows discharge area.

The most probable estimate of groundwater flow moving past underground nuclear testing areas in Yucca Flat sub-basin is less than 600 acre-feet per year (acre-ft/yr). Areas contributing groundwater flow to Yucca Flat extend from Rainier Mesa to the west, the Halfpint Range to the east, and north of Quartzite Ridge. Groundwater-flow rates through the transmissive corridor in Yucca Flat ranged from 660 to 1,100 acre-ft/yr using harmonic and geometric mean transmissivity-width products, respectively. These estimates are biased high because the transmissivity-width approach assumes a constant hydraulic gradient over an approximately 6-mi distance and does not account for head losses where strong transmissivity contrasts occur in the computed area.

\section{Acknowledgments}

The authors gratefully acknowledge the following reviewers of this report for their time, effort, and constructive comments: Edward M. Kwicklis of Los Alamos National Laboratory; Peter Martian of Navarro-Intera, LLC; and Joseph M Fenelon and Philip Gardner of the U.S. Geological Survey.

\section{References Cited}

Bechtel Nevada, 2004, Completion report for well cluster ER-6-1: U.S. Department of Energy Report DOE/ NV/11718-862, $134 \mathrm{p}$.

Bechtel Nevada, 2006, A hydrostratigraphic model and alternatives for the groundwater flow and contaminant transport model of Corrective Action Unit 97-Yucca FlatClimax Mine, Lincoln and Nye Counties, Nevada: U.S. Department of Energy Report DOE/NV/11718-1119, 288 p.

Belcher, W.R., and Sweetkind, D.S., eds., 2010, Death Valley regional groundwater flow system, Nevada and CaliforniaHydrogeologic framework and transient groundwater flow model, U.S. Geological Survey Professional Paper $1711,398 \mathrm{p}$.

Belcher, W.R., Sweetkind, D.S., Faunt, C.C., Pavelko, M.T., and Hill, M.C., 2017, An update of the Death Valley regional groundwater flow system transient model, Nevada and California: U.S. Geological Survey Scientific Investigations Report 2016-5150, 74 p., 1 pl., https://doi.org/10.3133/sir20165150.

Doherty, J., 2016, PEST-Model-independent parameter estimation, User manual part I-PEST, SENSAN, and global optimisers 6th ed.: Brisbane, Australia, Watermark Numerical Computing, 366 p., http://www.pesthomepage.org/Downloads.php

Federal Facility Agreement and Consent Order, 1996, Corrective action strategy-Underground test area, appendix VI (rev. 5, June 2014) of Federal facility agreement and consent order, agreed to by the State of Nevada, the U.S. Department of Energy, and the U.S. Department of Defense. 
Fenelon, J.M., Halford, K.J., and Moreo, M.T., 2016, Delineation of the Pahute Mesa-Oasis Valley groundwater basin, Nevada (ver. 1.1, May 2016): U.S. Geological Survey Scientific Investigations Report 2015-5175, 40 p., https://doi.org/10.3133/sir20155175.

Fenelon, J.M., Sweetkind, D.S., Elliott, P.E., and Laczniak, R.J., 2012, Conceptualization of the predevelopment groundwater flow system and transient water-level responses in Yucca Flat, Nevada National Security Site, Nevada: U.S. Geological Survey Scientific Investigations Report 2012-5196, 61 p.

Fenelon, J.M., Sweetkind, D.S., and Laczniak, R.J., 2010, Groundwater flow systems at the Nevada Test Site, Nevada - A synthesis of potentiometric contours, hydrostratigraphy, and geologic structures: U.S. Geological Survey Professional Paper 1771, 54 p., 6 pls.

Fletcher, T., 2018, Model H-310 WaterLOG series owner's manual (rev. 2.7): Design Analysis Associates, Incorporated, $40 \mathrm{p}$.

Foxboro Company, 1997, I/A series ${ }^{\circledR}$ magnetic flow transmitter model IMT25 with 8000 and $8000 \mathrm{~A}$ series water body flowtubes and 2800,8300, and 9300A series flanged flowtubes - Installation: Foxboro, Massachusetts, Foxboro Company, installation instructions, $60 \mathrm{p}$.

Fulford, J.M., and Clayton, C.S., 2015, Accuracy testing of steel and electric groundwater-level measuring tapes-Test method and in-service tape accuracy: U.S. Geological Survey Open-File Report 2015-1137, 31 p., https://doi.org/10.3133/ofr20151137.

Garcia, C.A., Halford, K.J., and Fenelon, J.M., 2013, Detecting drawdowns masked by environmental stresses with water-level models: Ground Water, v. 51, no. 3, p. 322-332.

Garcia, C.A., Jackson, T.R., Halford, K.J., Sweetkind, D.S., Damar, N.A., Fenelon, J.M., and Reiner, S.R., 2017, Hydraulic characterization of volcanic rocks in Pahute Mesa using an integrated analysis of 16 multiple-well aquifer tests, Nevada National Security Site, 2009-14: U.S. Geological Survey Scientific Investigations Report 2016-5151, 62 p., https://doi.org/10.3133/sir20165151.

Halford, K., Garcia, C.A., Fenelon, J., and Mirus, B., 2012, Advanced methods for modeling water-levels and estimating drawdowns with SeriesSEE, an Excel add-in (ver. 1.1, July 2016): U.S. Geological Survey Techniques and Methods, book 4, chap. F4, 28 p., https://dx.doi.org/10.3133/tm4F4.
Halford, K.J., and Jackson, T.R., in press, Groundwater characterization and effects of pumping in the Death Valley regional groundwater flow system, Nevada and California, with special reference to Devils Hole: U.S. Geological Survey Professional Paper 1863.

Harbaugh, A.W., 1990, A computer program for calculating subregional water budgets using results from the U.S. Geological Survey modular three-dimensional ground-water flow model: U.S. Geological Survey Open-File Report 90-392, $46 \mathrm{p}$.

Harbaugh, A.W., 2005, MODFLOW-2005-The U.S. Geological Survey modular ground-water modelThe ground-water flow process: U.S. Geological Survey Techniques and Methods, book 6, chap. A16 [variously paged].

Harrill, J.R., Gates, J.S., and Thomas, J.M., 1988, Major ground-water flow systems in the Great Basin region of Nevada, Utah, and adjacent States: U.S. Geological Survey Hydrologic Investigations Atlas HA-694-C, 2 sheets.

Harrill, J.R., and Prudic, D.E., 1998, Aquifer systems in the Great Basin region of Nevada, Utah, and adjacent statesSummary report: U.S. Geological Survey Professional Paper 1409-A, $66 \mathrm{p}$.

Harrison, J.C., 1971, New computer programs for the calculation of earth tides: Boulder, Colorado, Cooperative Institute for Research in Environmental Sciences, National Oceanic and Atmospheric Administration/University of Colorado, $58 \mathrm{p}$.

Jackson, T.R., 2017, AQUIFER TEST PACKAGEDrawdown estimation and analysis of the ER-4-1 $\mathrm{m} 1$ multiple-well aquifer test of the lower carbonate aquifer, Yucca Flat, Nevada National Security Site: U.S. Geological Survey memorandum, accessed June 1, 2017, at https://nevada.usgs.gov/water/aquifertests/? studyname $=$ ER $-4-1 \mathrm{~m} 1$.

Jackson, T.R., Halford, K.J., and Fenelon, J.M., 2019, Supplemental data for estimation of groundwater flow through Yucca Flat based on a multiple-well aquifer test at well ER-6-1-2 main, Nevada National Security Site, southern Nevada: U.S. Geological Survey data release, https://doi.org/10.5066/P9U2WG04.

Laczniak, R.J., Cole, J.C., Sawyer, D.A., and Trudeau, D.A., 1996, Summary of hydrogeologic controls on ground-water flow at the Nevada Test Site, Nye County, Nevada: U.S. Geological Survey Water-Resources Investigations Report 96-4109, 59 p. 
Laczniak, R.J., DeMeo, G.A., Reiner, S.R., Smith, J.L., and Nylund, W.E., 1999, Estimates of ground-water discharge as determined from measurements of evapotranspiration, Ash Meadows Area, Nye County, Nevada: U.S. Geological Survey Water-Resources Investigations Report 99-4079, $77 \mathrm{p}$.

Navarro-Intera, LLC, 2013, Phase I Flow and Transport Model Document for Corrective Action Unit 97: Yucca Flat/Climax Mine, Nevada National Security Site, Nye County, Nevada: Las Vegas, Nevada, Navarro-Intera Report $\mathrm{N}-\mathrm{I} / 28091-080,1,661 \mathrm{p}$.

Navarro-Intera, LLC, 2015, External peer review team report for Corrective Action Unit 97-Yucca Flat/Climax Mine, Nevada National Security Site, Nye County, Nevada: Las Vegas, Nevada, Navarro-Intera Report $\mathrm{N}-\mathrm{I} / 28091-091,265 \mathrm{p}$.

Prudic, D.E., Harrill, J.R., and Burbey, T.J., 1995, Conceptual evaluation of regional ground-water flow in the carbonate-rock province of the Great Basin, Nevada, Utah, and adjacent states: U.S. Geological Survey Professional Paper 1409-D, 102 p.

RamaRao, B.S., LaVenue, A.M., De Marsily, G., and Marietta, M.G., 1995, Pilot point methodology for automated calibration of an ensemble of conditionally simulated transmissivity fields - 1 . Theory and computational experiments: Water Resources Research, v. 31, no. 3, p. 475-493.

Sawyer, D.A., Fleck, R.J., Lanphere, M.A., Warren, R.G., Broxton, D.E., and Hudson, M.R., 1994, Episodic caldera volcanism in the Miocene southwestern Nevada volcanic field-Revised stratigraphic framework, Ar40/ Ar39 geochronology and implications for magmatism and extension: Geological Society of America Bulletin, v. 106, no. 10 , p. 1304-1318.

Seametrics, 2018, INW PS98i/PS9800 submersible pressure transmitter instructions: Kent, Washington, Seametrics manual, $12 \mathrm{p}$.

Slate, J.L., Berry, M.E., Rowley, P.D., Fridrich, C.J., Morgan, K.S., Workman, J.B., Young, O.D., Dixon, G.L., Williams, V.S., McKee, E.H., Ponce, D.A., Hildenbrand, T.G., Swadley, W.C., Lundstrom, S.C., Ekren, E.B., Warren, R.G., Cole, J.C., Fleck, R.J., Lanphere, M.A., Sawyer, D.A., Minor, S.A., Grunwald, D.J., Laczniak, R.J., Menges, C.M., Yount, J.C., and Jayko, A.S., 1999, Digital geologic map of the Nevada Test Site and vicinity, Nye, Lincoln, and Clark Counties, Nevada, and Inyo County, California: U.S. Geological Survey Open-File Report 99-554A, 53 p., 1 pl., scale 1:120,000, accessed June 2011, at https://pubs.usgs.gov/of/1999/ofr-99-0554/.
Stoller-Navarro Joint Venture, 2005, ER-6-1 well cluster multiple well aquifer test-Tracer test data reportVolumes 1, 2, and 3-Preliminary (rev. 0): Las Vegas, Nevada, Stoller-Navarro Joint Venture, 695 p.

Stoller-Navarro Joint Venture, 2006, Phase I hydrologic data for the groundwater flow and contaminant transport model of Corrective Action Unit 97-Yucca Flat/Climax Mine, Nevada Test Site, Nye County, Nevada: Stoller-Navarro Joint Venture Report S-N/99205-077, 643 p.

Sweetkind, D.S., Belcher, W.R., Faunt, C.C., and Potter, C.J., 2010, Geology and hydrogeology, chap. B of Belcher, W.R., and Sweetkind, D.S., eds., Death Valley regional ground-water flow system, Nevada and CaliforniaHydrogeologic framework and transient ground-water flow model: U.S. Geological Survey Professional Paper 1711, p. 19-94, https://pubs.usgs.gov/pp/1711/.

Theis, C.V., 1935, The relation between the lowering of the piezometric surface and the rate and duration of discharge of a well using groundwater storage: Transactions American Geophysical Union, v. 16, no. 2, p. 519-524.

U.S. Department of Energy, 2000, Corrective action investigation plan for Corrective Action Unit 97-Yucca Flat/Climax Mine, Nevada Test Site, Nevada: U.S. Department of Energy Report DOE/NV-659, 381 p.

U.S. Department of Energy, 2015, United States nuclear tests, July 1945 through September 1992: U.S. Department of Energy Report DOE/NV-209 REV 16, 129 p.

U.S. Environmental Protection Agency, 2012, National primary drinking water regulations: Code of Federal Regulations, Title 40, Part 141.

Vaisala, 2005, PTB100 analog barometer: Helsinki, Finland, Vaisala instruments catalog, p. 112-113, accessed April 3, 2019, at https://envcoglobal.com/files/ docs/---ptb100brochureinenglish.pdf.

Winograd, I.J., and Thordarson, W., 1975, Hydrogeologic and hydrochemical framework, south-central Great Basin, Nevada-California, with special reference to the Nevada Test Site: U.S. Geological Survey Professional Paper 712-C, 126 p.

Winograd, I.J., and Pearson, F.J., Jr., 1976, Major carbon 14 anomaly in a regional carbonate aquifer-Possible evidence for megascale channeling, south central Great Basin: Water Resources Research, v. 12, no. 6, p. 1125-1143.

Ye, M., Pohlmann, K.F., Chapman, J.B., Pohll, G.M., and Reeves, D.M., 2010, A model-averaging method for assessing groundwater conceptual model uncertainty: Ground Water, v. 48, no. 5, p. 716-728, https://doi.org/10.1111/j.1745-6584.2009.00633.x. 

Publishing support provided by the U.S. Geological Survey Science Publishing Network, Tacoma Publishing Service Center

For more information concerning the research in this report, contact the Director, Nevada Water Science Center

U.S. Geological Survey

2730 N. Deer Run Road

Carson City, Nevada 95819 


\section{密}

